\title{
Article \\ Effect of Rice Grain (Oryza sativa L.) Enrichment with Selenium on Foliar Leaf Gas Exchanges and Accumulation of Nutrients
}

\author{
Ana Coelho Marques 1,2,*(D), Fernando C. Lidon ${ }^{1,2}$, Ana Rita F. Coelho 1,2 (D) Cláudia Campos Pessoa 1,2 (D), \\ Inês Carmo Luís ${ }^{1,2} \mathbb{D}_{\text {, Paula Scotti Campos }}^{2,3} \mathbb{D}^{-}$, Manuela Simões ${ }^{1,2} \mathbb{D}_{\text {, Ana Sofia Almeida }}{ }^{2,4}$ (D), \\ Maria F. Pessoa ${ }^{1,2} \mathbb{D}$, Carlos Galhano ${ }^{1,2}$, Mauro Guerra ${ }^{5} \mathbb{D}$, Roberta G. Leitão ${ }^{\mathbb{D}}$, Paulo Legoinha ${ }^{1,2} \mathbb{D}$, \\ José C. Ramalho ${ }^{2,6}{ }^{(D}$, José N. Semedo ${ }^{2,3}{ }^{\mathbb{D}}$, Ana Paula Rodrigues ${ }^{6}{ }^{\mathbb{D}}$, Paula Marques ${ }^{7}$, Cátia Silva ${ }^{7}$, \\ Ana Ribeiro-Barros ${ }^{2,6}{ }^{\mathbb{D}}$, Maria José Silva ${ }^{2,6}$, Maria Manuela Silva ${ }^{8} \mathbb{D}$, Karliana Oliveira ${ }^{2,9}$, David Ferreira ${ }^{1}$, \\ Isabel P. Pais ${ }^{2,3}$ and Fernando H. Reboredo ${ }^{1,2}$
}

check for updates

Citation: Marques, A.C.; Lidon, F.C.; Coelho, A.R.F.; Pessoa, C.C.; Luís, I.C.; Campos, P.S.; Simões, M.;

Almeida, A.S.; Pessoa, M.F.;

Galhano, C.; et al. Effect of Rice Grain (Oryza sativa L.) Enrichment with Selenium on Foliar Leaf Gas

Exchanges and Accumulation of Nutrients. Plants 2021, 10, 288. https://doi.org/10.3390/ plants10020288

Received: 31 December 2020

Accepted: 29 January 2021

Published: 3 February 2021

Publisher's Note: MDPI stays neutral with regard to jurisdictional claims in published maps and institutional affiliations.

Copyright: (c) 2021 by the authors. Licensee MDPI, Basel, Switzerland. This article is an open access article distributed under the terms and conditions of the Creative Commons Attribution (CC BY) license (https:// creativecommons.org/licenses/by/ $4.0 /)$.
1 Earth Sciences Department, Faculdade de Ciências e Tecnologia, Universidade Nova de Lisboa, Campus da Caparica, 2829-516 Caparica, Portugal; fjl@fct.unl.pt (F.C.L.); arf.coelho@campus.fct.unl.pt (A.R.F.C.); c.pessoa@campus.fct.unl.pt (C.C.P.); idc.rodrigues@campus.fct.unl.pt (I.C.L.); mmsr@fct.unl.pt (M.S.); mfgp@fct.unl.pt (M.F.P.); acag@fct.unl.pt (C.G.); pal@fct.unl.pt (P.L.); djo.ferreira@campus.fct.unl.pt (D.F.); fhr@fct.unl.pt (F.H.R.)

2 GeoBioTec Research Center, Faculdade de Ciências e Tecnologia, Universidade Nova de Lisboa, Campus da Caparica, 2829-516 Caparica, Portugal; paula.scotti@iniav.pt (P.S.C.); sofia.almeida@iniav.pt (A.S.A.); cochichor@mail.telepac.pt (J.C.R.); jose.semedo@iniav.pt (J.N.S.); aribeiro@isa.ulisboa.pt (A.R.-B.); mjsilva@isa.ulisboa.pt (M.J.S.); karliana.oliveira@ipbeja.pt (K.O.); isabel.pais@iniav.pt (I.P.P.)

3 Instituto Nacional de Investigação Agrária e Veterinária, I.P. (INIAV), Avenida da República, Quinta do Marquês, 2780-157 Oeiras, Portugal

4 Instituto Nacional de Investigação Agrária e Veterinária, I.P. (INIAV), Estrada de Gil Vaz 6, 7351-901 Elvas, Portugal

5 LIBPhys, Physics Department, Faculdade de Ciências e Tecnologia, Universidade Nova de Lisboa, Campus da Caparica, 2829-516 Caparica, Portugal; mguerra@fct.unl.pt (M.G.); rg.leitao@fct.unl.pt (R.G.L.)

6 PlantStress \& Biodiversity Lab., Centro de Estudos Florestais (CEF), Instituto Superior Agronomia (ISA), Universidade de Lisboa (ULisboa), Quinta do Marquês, Av. República, 2784-505, Oeiras and Tapada da Ajuda, 1349-017 Lisboa, Portugal; anadr@isa.ulisboa.pt

7 Centro Operativo e Tecnológico do Arroz (COTARROZ), 2120-014 Salvaterra de Magos, Portugal; p.marques@cotarroz.pt (P.M.); catia.leonardo.silva@gmail.com (C.S.)

8 Escola Superior de Educação Almeida Garrett (ESEAG-COFAC), Avenida do Campo Grande 376, 1749-024 Lisboa, Portugal; abreusilva.manuela@gmail.com

9 Instituto Politécnico de Beja (IPBeja), 7800-295 Beja, Portugal

* Correspondence: amc.marques@campus.fct.unl.pt

Abstract: An agronomic itinerary for Se biofortification of two rice cultivars (Ariete and Ceres) through foliar fertilization with sodium selenate and sodium selenite with different concentrations $(25,50,75$

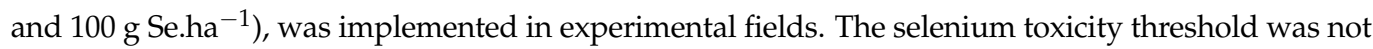
exceeded, as shown by the eco-physiological data obtained through leaf gas exchanges. The highest Se enrichment in paddy grains was obtained with selenite for both cultivars, especially at the highest doses, i.e., 75 and $100 \mathrm{~g}$ Se.ha ${ }^{-1}$, with approximately a 5.0-fold increase compared with control values. In paddy grains, $\mathrm{Zn}$ was the most affected element by the treatments with Se with decreases up to $54 \%$. When comparing the losses between rough and polished grains regardless of the cultivars, Se species and concentrations, it was observed that only $\mathrm{Cu}, \mathrm{Mg}$ and $\mathrm{Zn}$ exhibited losses $<50 \%$. The remaining elements generally had losses $>70 \%$. The loss of Se is more pronounced in Ceres cultivar than in Ariete but rarely exceeds $50 \%$. The analysis by $\mu$-EDXRF showed that, in Ariete cultivar, Se is mostly homogeneously distributed in the grain regardless of any treatments, while in Ceres cultivar, the Se distribution seems to favor accumulation in the periphery, perhaps in the bran.

Keywords: elemental composition; photosynthesis; rice cultivars; selenium biofortification 


\section{Introduction}

Selenium is an essential element in the human diet, although its presence in plants is scarce [1]. The application of Se in the form of sodium selenate [2,3] or sodium selenite [4] is a useful and well-known method to increase the Se concentration in food crops. Studies show that foliar spraying with Se is more viable and effective than its application to the soil [5]. Roots can mobilize Se in the forms of selenate, selenite, elemental Se and organic compounds such as SeCys (seleno-cysteine) and SeMeth (seleno-methionine) [6], although soil speciation is regulated by both $\mathrm{pH}$ and $\mathrm{Eh}$-selenite is the main form in anaerobic soils with a neutral to acidic $\mathrm{pH}$, as occurs in paddy fields, while selenate is in the main water soluble form in oxic soils [6].

Foliar spraying is affected by leaf anatomy beyond substrata characteristics and environmental factors. In general, after foliar Fe application, it takes between 10 and 20 days to absorb 50\% of the micronutrient [7], although for Ca, Mn and Zn only 1-2 days were needed for $50 \%$ absorption, which agrees with the promising results of foliar fertilizer application to improve grain $\mathrm{Zn}$ in wheat and other cereals [8]. The effectiveness of foliar feeding was seen after evaluation of the Se rice grain concentrations which increased to $0.471-0.640 \mu \mathrm{g} \mathrm{g}^{-1}$, after using a Se enriched fertilizer at a rate of $20 \mathrm{~g}$ of Se.ha ${ }^{-1}$, in the forms of sodium selenite and sodium selenate, when the average Se content of regular polished rice in China is $0.025 \pm 0.011 \mu \mathrm{g} \mathrm{g}^{-1}$ [9].

Several studies confirmed that selenate is more effective than selenite (applied either through soil or foliar spray) regarding cereal enrichment [10-12] while others point out to selenite $[13,14]$. Thus, the forms of Se supply but also genotype differences, plus the substrata characteristics affect the Se bioavailability by plant cultivars.

The Se of selenate is more easily transported to the aerial part while the Se of selenite tends to accumulate in the roots, indicating different absorption and mobility routes [15]. Hawrylak-Nowak observed that the Se concentration in lettuce (edible part) increased as a function of the increasing concentrations of selenite and selenate applied in hydroponic cultures, with values ranging between 3.7 and 30.6 and 4.7 and $43.3 \mathrm{mg} \mathrm{kg}^{-1}$, for selenite and selenate, respectively [16]. Conversely, the concentrations of Se in the roots ranged between 48.5 and 201.4 and 1.9 and $44.2 \mathrm{mg} \mathrm{kg}^{-1}$, for selenite and selenate, respectively, clearly indicating that the translocation to the aerial organs is poor when selenite is used, but not the uptake.

Thus, through agronomic biofortification it is possible to increase the intake of Se by humans, due to the Se enrichment of main food crops such as rice [14,17-19] wheat $[2,20]$ potato [21] and lettuce [16], for example. Selenium is also beneficial in defending plants against oxidative stress caused by oxygen radicals produced by internal metabolic or external factors [22] also delaying the effects of senescence at appropriate levels.

Regarding the interaction of Se with other nutrients, studies with biofortified wheat plants with different concentrations of selenate and selenite have shown that micronutrients were more affected by the presence of Se than macronutrients, and the elements that accumulate more in the roots $(\mathrm{Ca}, \mathrm{Fe}, \mathrm{Mn}$ and $\mathrm{Zn})$ were more sensitive to the presence of Se [23]. The rice plant has a tendency to absorb Fe because ferrous ion is abundant in flooded soils and reduced iron is easily absorbed [24]. Moreover, the assimilation of Se into organoselenium compounds is supposed to compete with the assimilation of S [25], while the application of $\mathrm{P}$ fertilizer to the soil increases the concentration of Se in wheat in selenate-fertilized calcareous soils, but not in selenite-fertilized [26].

The accumulation of $\mathrm{Mn}, \mathrm{Fe}$ and $\mathrm{Zn}$ in two wheat seedling cultivars showed that the plants supplied with $2 \mu \mathrm{M} \mathrm{Na}_{2} \mathrm{SeO}_{4}$ over two weeks did not exhibit significant differences in the overwhelming majority of the cases, regarding the $\mathrm{Mn}, \mathrm{Fe}$ and $\mathrm{Zn}$ content, compared with the control plants [27].

The japonica rice Ariete is appreciated by farmers because of its production and quality. Ariete has been widely cultivated throughout Europe, and today it ranks as the main cultivar in Portugal, accounting for 40\% of the total area cultivated in 2010 [28]. Each year, tests are carried out on new genetic improvement cultivars with a view to introducing 
and replacing cultivars that meet the needs of producers and industry. Ceres was the first Portuguese cultivar of carolino rice to be listed in the national catalog of cultivars. Ariete and Ceres rice grains are classified as long (grain length/width ratio of 2.6 and 2.5), with average amylose of $15.3 \%$ and $18.2 \%$, respectively [29]. Considering the importance of Oryza sativa L. worldwide, this study aimed to develop an agronomic itinerary leading to Se rice enrichment, while evaluating photosynthetic metabolism, and the impact of the application of Se on macro and micronutrients rice grains, in both paddy, brown and polished forms. Furthermore, the distribution of Se in grain was also studied by $\mu$-EDXRF.

\section{Results}

\subsection{Physiological Monitoring during Biofortification}

Physiological data were acquired after the second foliar Se fertilization in rice leaves treated with the two highest concentrations of selenite and selenate, beyond the controls.

The Ariete plants did not show any significant impact on net photosynthesis $\left(\mathrm{P}_{\mathrm{n}}\right)$, regardless of the form $\left(\mathrm{Na}_{2} \mathrm{SeO}_{4}\right.$ or $\left.\mathrm{Na}_{2} \mathrm{SeO}_{3}\right)$ or dose $\left(50\right.$ or $\left.100 \mathrm{~g} \mathrm{Se} . \mathrm{ha}^{-1}\right)$, despite a minor tendency of higher values in the Se-Treated plants (Figure 1). In contrast, all Setreated plants showed significant increases in stomatal conductance to water vapor $\left(g_{s}\right)$, in particular in those of the $100 \mathrm{~g}$ Se.ha ${ }^{-1}$ of $\mathrm{Na}_{2} \mathrm{SeO}_{3}$ treatment which doubled its value. This $\mathrm{g}_{\mathrm{s}}$ rise was paralleled with significant transpiration (E) increases, whereas instantaneous water use efficiency (iWUE) was reduced significantly for both treatments and cultivars.

The cultivar Ceres showed a similar pattern of changes to that of Ariete as regards the leaf gas exchanges. After two foliar applications, there was no negative impact on $P_{n}$ of any of the Se-treatments. In fact, $P_{n}$ was significantly increased by the $50 \mathrm{~g}$ Se.ha ${ }^{-1}$ of $\mathrm{Na}_{2} \mathrm{SeO}_{4}$ treatment, and, especially with the maximum doses of both selenite and selenite compounds, always as compared to the control (Figure 1). Plants treated with the highest selenite or selenate concentrations showed a tendency to display higher $\mathrm{g}_{\mathrm{s}}$ and E values, although significantly only for $\mathrm{Na}_{2} \mathrm{SeO}_{3}$ cultivar. Still, no significant impacts were found for iWUE in Ceres (Figure 1).

\subsection{Accumulation of Selenium in Rice Grain}

It was found that, at harvest, the average yields $\left(\mathrm{kg} \mathrm{ha}^{-1}\right)$ were, for Ariete, 4810 and 4548 and, for Ceres, 5499 and 5322 (for both cultivars, after application of selenate and selenite, respectively). In general, an increase in Se concentration in the paddy grain of both cultivars as a function of increasing doses of foliar spraying was observed, although

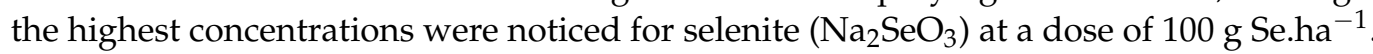
It is interesting to note a growing enrichment of Se grains as the concentration of Sefertilizer increases, although in Ceres cultivar treated with selenite it seems that a threshold enrichment was reached since the concentrations verified with 50,75 and $100 \mathrm{~g}^{\text {Se.ha }}{ }^{-1}$ are very similar (Table 1 ).

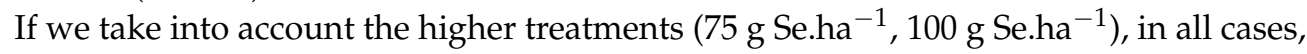
the concentrations of $\mathrm{Se}$ in the grains of both cultivars treated with selenite $\left(\mathrm{Na}_{2} \mathrm{SeO}_{3}\right)$ contained more Se than those treated with selenate $\left(\mathrm{Na}_{2} \mathrm{SeO}_{4}\right)$. The levels of Se in the control grains were very low generally around $2 \mathrm{mg} \mathrm{kg}^{-1}$.

The concentrations of Se within grain cultivars often decrease as the grains are dehusked and polished. White grains (polished) from Ceres cultivar treated with $75 \mathrm{~g}$ and $100 \mathrm{~g}$ Se.ha ${ }^{-1}$ selenate contained $43.8 \%$ and $54.4 \%$ less Se than equivalent treatments in brown grains, and $56.6 \%$ and $62.9 \%$ less if paddy grains were considered. In the same context (cultivar and concentrations) the decrease in Se in polished grains when selenite was applied was a little bit lower, i.e., $8 \%$ and $13.4 \%$ in $75 \mathrm{~g}$ and $100 \mathrm{~g} \mathrm{Se.ha}^{-1}$, respectively (Tables 1-3). 

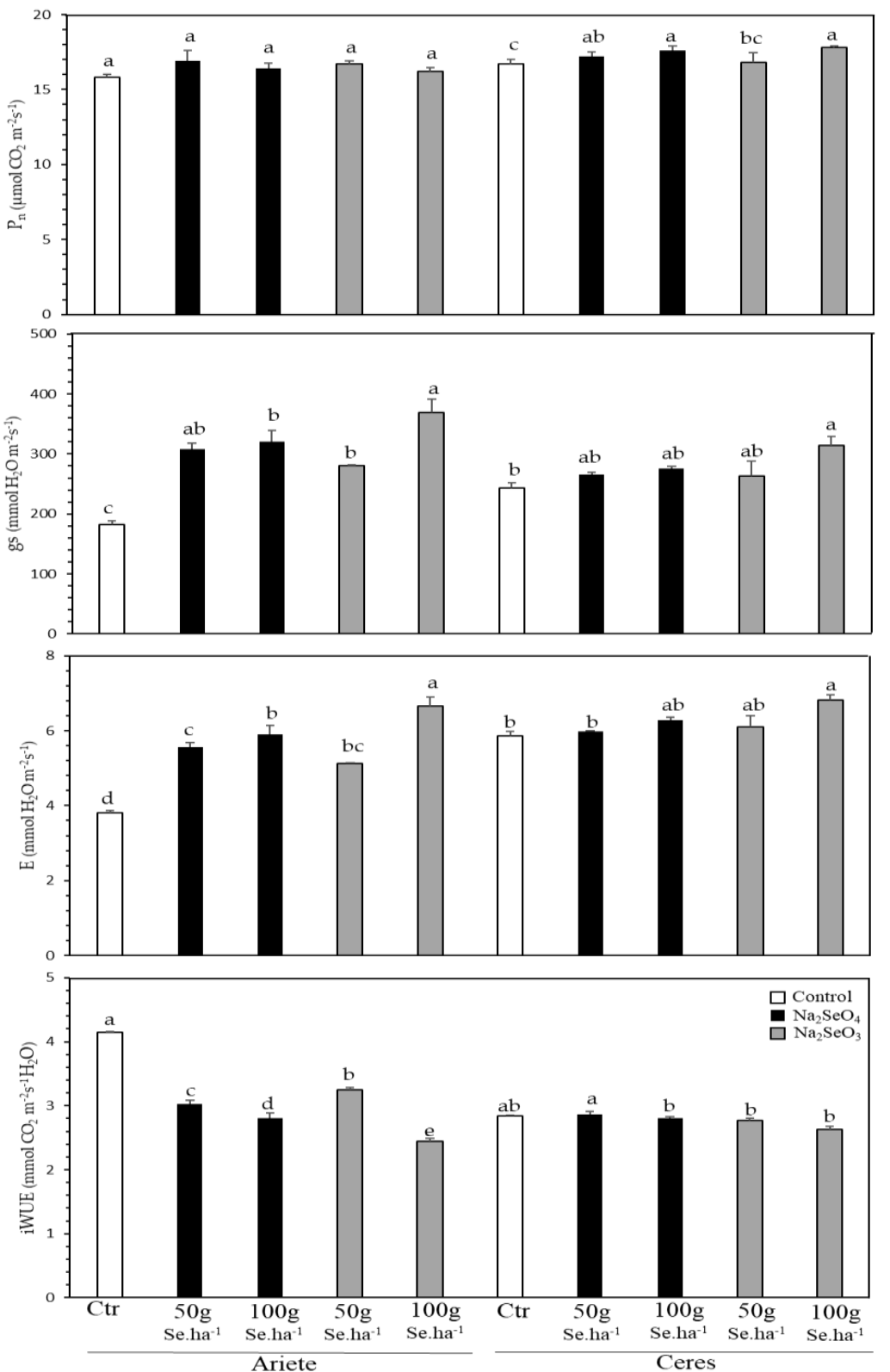

Figure 1. Leaf gas exchange parameters-net photosynthesis $\left(P_{n}\right)$, stomatal conductance to water vapor $\left(\mathrm{g}_{\mathrm{s}}\right)$, transpiration (E) rates, and instantaneous water use efficiency (iWUE) in leaves of $O$. sativa, cultivars Ariete and Ceres. Different letters indicate significant differences between treatments, for each cultivar $(p \leq 0.05)$; average \pm standard errors $(n=4-6)$. 
Table 1. Selenium, zinc, iron, copper, calcium, magnesium and potassium concentrations in the paddy grains of $O$. sativa cultivars.

\begin{tabular}{|c|c|c|c|c|c|c|c|c|c|}
\hline & $\begin{array}{l}\text { Trea } \\
\text { (g S }\end{array}$ & $\begin{array}{l}\text { ents } \\
\left.1^{-1}\right)\end{array}$ & Se & $\mathrm{Zn}$ & $\mathrm{Fe}$ & $\mathrm{Cu}$ & $\mathrm{Ca}$ & Mg & $\mathbf{K}$ \\
\hline \multirow{10}{*}{ 怤 } & \multirow{5}{*}{$\begin{array}{l}\overbrace{}^{+} \\
\text {W } \\
\text { Z }\end{array}$} & Control & $1.69 \pm 0.20^{c}$ & $47.0 \pm 11.4^{\mathrm{a}}$ & $34.9 \pm 2.4^{\mathrm{a}}$ & $5.13 \pm 0.87^{\mathrm{a}}$ & $43.9 \pm 7.07^{\mathrm{a}}$ & $443 \pm 3.49^{\mathrm{a}}$ & $6300 \pm 1000^{b}$ \\
\hline & & 25 & $2.66 \pm 0.23^{c}$ & $36.0 \pm 2.76^{a}$ & $35.1 \pm 3.02^{\mathrm{a}}$ & $4.85 \pm 0.05^{\mathrm{a}}$ & $42.4 \pm 7.89^{a}$ & $448 \pm 2.58^{a}$ & $6300 \pm 200^{b}$ \\
\hline & & 50 & $4.06 \pm 1.38^{b}$ & $26.8 \pm 4.14^{b}$ & $38.5 \pm 5.49^{a}$ & $5.35 \pm 0.93^{a}$ & $21.9 \pm 5.89^{a}$ & $445 \pm 0.40^{\mathrm{a}}$ & $8900 \pm 1600^{a}$ \\
\hline & & 75 & $6.06 \pm 0.42^{a b}$ & $30.3 \pm 4.44^{\mathrm{a}}$ & $35.0 \pm 2.36^{\mathrm{a}}$ & $5.19 \pm 0.51^{a}$ & $27.1 \pm 6.22^{\mathrm{a}}$ & $418 \pm 6.57^{b}$ & $8200 \pm 2100^{a}$ \\
\hline & & 100 & $8.10 \pm 2.21^{a}$ & $30.7 \pm 6.34^{\mathrm{a}}$ & $36.8 \pm 5.90^{a}$ & $5.94 \pm 1.05^{a}$ & $30.9 \pm 8.13^{a}$ & $415 \pm 9.10^{b}$ & $8700 \pm 1400^{a}$ \\
\hline & \multirow{5}{*}{$\begin{array}{l}\overbrace{\mathbb{N}}^{\infty} \\
\stackrel{\mathbb{N}}{Z} \\
\tilde{Z}\end{array}$} & Control & $1.69 \pm 0.20^{c}$ & $47.0 \pm 11.4^{\mathrm{a}}$ & $34.9 \pm 2.40^{\mathrm{a}}$ & $5.13 \pm 0.87^{a}$ & $43.9 \pm 7.07^{\mathrm{a}}$ & $443 \pm 3.49^{\mathrm{a}}$ & $6300 \pm 1000^{b}$ \\
\hline & & 25 & $5.92 \pm 2.38^{a b}$ & $28.3 \pm 2.42^{b}$ & $31.0 \pm 6.52^{\mathrm{a}}$ & $5.34 \pm 0.63^{a}$ & $40.0 \pm 5.09^{a}$ & $440 \pm 2.77^{a}$ & $9400 \pm 900^{a}$ \\
\hline & & 50 & $7.55 \pm 1.79^{a b}$ & $33.0 \pm 6.77^{\mathrm{a}}$ & $39.6 \pm 3.12^{a}$ & $5.30 \pm 0.76^{a}$ & $44.7 \pm 8.83^{\mathrm{a}}$ & $449 \pm 9.00^{\mathrm{a}}$ & $8700 \pm 2300^{a}$ \\
\hline & & 75 & $9.88 \pm 2.83^{\mathrm{a}}$ & $31.6 \pm 3.28^{\mathrm{a}}$ & $35.8 \pm 5.71^{\mathrm{a}}$ & $5.79 \pm 0.17^{a}$ & $45.3 \pm 6.11^{\mathrm{a}}$ & $441 \pm 4.45^{\mathrm{a}}$ & $9000 \pm 1400^{a}$ \\
\hline & & 100 & $13.0 \pm 2.52^{\mathrm{a}}$ & $29.6 \pm 3.12^{b}$ & $39.2 \pm 12.7^{a}$ & $5.02 \pm 0.84^{\mathrm{a}}$ & $39.8 \pm 8.98^{a}$ & $456 \pm 5.88^{a}$ & $6900 \pm 300^{b}$ \\
\hline \multirow{10}{*}{ 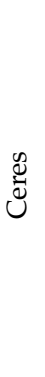 } & \multirow{5}{*}{$\begin{array}{l}\text { Oే } \\
\text { W } \\
\widetilde{N} \\
Z\end{array}$} & Control & $2.01 \pm 0.32^{c}$ & $69.7 \pm 1.74^{\mathrm{a}}$ & $42.7 \pm 4.59^{\mathrm{a}}$ & $7.43 \pm 0.81^{a}$ & $76.1 \pm 2.99^{\mathrm{a}}$ & $424 \pm 11.2^{\mathrm{ab}}$ & $6700 \pm 600^{a b}$ \\
\hline & & 25 & $4.11 \pm 0.76^{b}$ & $36.5 \pm 3.90^{b}$ & $37.8 \pm 8.46^{\mathrm{a}}$ & $7.74 \pm 0.98^{a}$ & $59.1 \pm 5.29^{b}$ & $408 \pm 5.90^{b}$ & $8700 \pm 700^{a}$ \\
\hline & & 50 & $5.67 \pm 1.63^{\mathrm{a}}$ & $33.6 \pm 9.27^{b}$ & $40.1 \pm 5.59^{a}$ & $6.50 \pm 2.21^{a}$ & $51.1 \pm 0.81^{b}$ & $453 \pm 20.3^{a}$ & $6100 \pm 700^{b}$ \\
\hline & & 75 & $8.66 \pm 3.25^{\mathrm{a}}$ & $31.4 \pm 1.94^{\mathrm{b}}$ & $43.7 \pm 8.92^{\mathrm{a}}$ & $6.53 \pm 1.19^{a}$ & $57.3 \pm 2.19^{b}$ & $418 \pm 12.9^{b}$ & $5500 \pm 500^{b}$ \\
\hline & & 100 & $11.6 \pm 3.94^{\mathrm{a}}$ & $49.3 \pm 16.0^{\mathrm{ab}}$ & $50.0 \pm 2.05^{a}$ & $7.10 \pm 1.07^{a}$ & $67.8 \pm 2.31^{a b}$ & $419 \pm 8.92^{b}$ & $7100 \pm 500^{a b}$ \\
\hline & \multirow{5}{*}{$\begin{array}{l}\overbrace{}^{\infty} \\
\mathbb{N} \\
\mathbb{Z} \\
Z\end{array}$} & Control & $2.01 \pm 0.32^{c}$ & $69.7 \pm 1.74^{\mathrm{a}}$ & $42.7 \pm 4.59^{\mathrm{a}}$ & $7.43 \pm 0.81^{a}$ & $76.1 \pm 2.99^{a}$ & $424 \pm 11.2^{b}$ & $6700 \pm 600^{a}$ \\
\hline & & 25 & $6.30 \pm 1.22^{b}$ & $39.2 \pm 5.22^{\mathrm{a}}$ & $51.0 \pm 9.84^{\mathrm{a}}$ & $7.26 \pm 1.40^{a}$ & $40.6 \pm 6.58^{b}$ & $437 \pm 8.57^{b}$ & $8200 \pm 900^{a}$ \\
\hline & & 50 & $11.8 \pm 3.85^{\mathrm{a}}$ & $36.7 \pm 7.97^{\mathrm{a}}$ & $40.2 \pm 4.28^{a}$ & $6.11 \pm 1.12^{\mathrm{a}}$ & $56.7 \pm 5.78^{b}$ & $457 \pm 4.38^{\mathrm{a}}$ & $6300 \pm 600^{a}$ \\
\hline & & 75 & $10.3 \pm 2.01^{\mathrm{a}}$ & $33.4 \pm 2.82^{\mathrm{a}}$ & $50.0 \pm 8.97^{a}$ & $5.75 \pm 0.71^{a}$ & $57.8 \pm 2.37^{b}$ & $429 \pm 3.88^{b}$ & $6000 \pm 1100^{a}$ \\
\hline & & 100 & $12.7 \pm 2.91^{\mathrm{a}}$ & $38.0 \pm 1.99^{a}$ & $45.2 \pm 8.25^{a}$ & $5.99 \pm 0.43^{a}$ & $58.4 \pm 7.53^{b}$ & $444 \pm 1.54^{b}$ & $6800 \pm 1500^{a}$ \\
\hline
\end{tabular}

Different letters within the same column, cultivar and treatment indicate significant differences $(p \leq 0.05)$. Average values are expressed in $\mathrm{mg} \mathrm{kg}^{-1} \pm$ standard deviation $(n=3)$.

Table 2. Selenium, zinc, iron, copper, calcium, magnesium and potassium concentrations in the brown grains of $O$. sativa cultivars.

\begin{tabular}{|c|c|c|c|c|c|c|c|c|c|}
\hline & $\begin{array}{l}\text { Trea } \\
\text { (g S }\end{array}$ & & Se & $\mathrm{Zn}$ & $\mathrm{Fe}$ & $\mathrm{Cu}$ & $\mathrm{Ca}$ & Mg & $\mathbf{K}$ \\
\hline \multirow{10}{*}{ 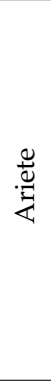 } & \multirow{5}{*}{$\begin{array}{l}O_{\mathbb{U}}^{+} \\
\text {W } \\
\text { Z }\end{array}$} & Control & $1.75 \pm 0.28^{c}$ & $29.5 \pm 6.08^{a}$ & $24.3 \pm 1.79^{a}$ & $5.48 \pm 0.65^{a}$ & $25.9 \pm 1.74^{\mathrm{a}}$ & $448 \pm 18.6^{\mathrm{a}}$ & $5300 \pm 100^{b}$ \\
\hline & & 25 & $2.86 \pm 0.37^{c}$ & $27.9 \pm 3.41^{\mathrm{a}}$ & $19.4 \pm 3.50^{\mathrm{a}}$ & $5.34 \pm 0.40^{\mathrm{a}}$ & $20.9 \pm 3.88^{a}$ & $438 \pm 6.87^{a}$ & $8500 \pm 1600^{a}$ \\
\hline & & 50 & $3.74 \pm 0.39^{a b}$ & $28.5 \pm 6.31^{a}$ & $18.5 \pm 5.47^{\mathrm{a}}$ & $5.05 \pm 1.35^{a}$ & $11.3 \pm 3.62^{b}$ & $453 \pm 4.22^{\mathrm{a}}$ & $7000 \pm 2000^{a}$ \\
\hline & & 75 & $5.51 \pm 1.50^{\mathrm{ab}}$ & $24.9 \pm 1.18^{a}$ & $14.6 \pm 2.60^{\mathrm{a}}$ & $4.41 \pm 0.57^{\mathrm{a}}$ & $18.4 \pm 4.13^{\mathrm{a}}$ & $447 \pm 6.74^{\mathrm{a}}$ & $6000 \pm 1400^{a}$ \\
\hline & & 100 & $7.17 \pm 1.84^{\mathrm{a}}$ & $28.9 \pm 4.74^{\mathrm{a}}$ & $15.9 \pm 2.44^{\mathrm{a}}$ & $4.96 \pm 0.12^{\mathrm{a}}$ & $13.1 \pm 2.49^{b}$ & $425 \pm 11.8^{a}$ & $6600 \pm 800^{a}$ \\
\hline & \multirow{5}{*}{$\begin{array}{l}0_{\mathscr{N}}^{\infty} \\
\underset{\mathbb{N}}{Z}\end{array}$} & Control & $1.75 \pm 0.28^{c}$ & $29.5 \pm 6.08^{a}$ & $24.3 \pm 1.79^{a}$ & $5.48 \pm 0.65^{\mathrm{a}}$ & $25.9 \pm 1.74^{b}$ & $448 \pm 18.6^{\mathrm{a}}$ & $5300 \pm 100^{b}$ \\
\hline & & 25 & $2.15 \pm 0.14^{c}$ & $27.6 \pm 6.06^{a}$ & $19.7 \pm 1.69^{a}$ & $4.20 \pm 0.48^{a}$ & $26.8 \pm 1.34^{b}$ & $443 \pm 5.46^{\mathrm{a}}$ & $5700 \pm 1500^{a}$ \\
\hline & & 50 & $6.76 \pm 1.32^{b}$ & $28.3 \pm 5.73^{a}$ & $17.5 \pm 0.96^{a}$ & $7.67 \pm 5.18^{a}$ & $45.1 \pm 11.0^{\mathrm{a}}$ & $454 \pm 7.04^{\mathrm{a}}$ & $4800 \pm 700^{a}$ \\
\hline & & 75 & $12.1 \pm 4.13^{\mathrm{ab}}$ & $27.6 \pm 4.21^{\mathrm{a}}$ & $19.8 \pm 1.00^{\mathrm{a}}$ & $4.96 \pm 0.71^{\mathrm{a}}$ & $33.0 \pm 2.78^{a}$ & $454 \pm 2.84^{\mathrm{a}}$ & $7700 \pm 600^{a}$ \\
\hline & & 100 & $16.7 \pm 4.30^{\mathrm{a}}$ & $26.1 \pm 6.07^{a}$ & $14.1 \pm 1.15^{\mathrm{a}}$ & $4.92 \pm 0.62^{\mathrm{a}}$ & $29.4 \pm 5.92^{a b}$ & $446 \pm 2.14^{\mathrm{a}}$ & $7300 \pm 2800^{a}$ \\
\hline \multirow{10}{*}{$\underbrace{\infty}_{0}$} & \multirow{5}{*}{$\begin{array}{l}O_{\mathbb{N}}^{+} \\
\mathbb{N}_{\mathbb{N}} \\
Z\end{array}$} & Control & $2.11 \pm 0.25^{\mathrm{c}}$ & $44.6 \pm 7.53^{\mathrm{a}}$ & $22.4 \pm 1.56^{\mathrm{a}}$ & $5.42 \pm 0.62^{\mathrm{a}}$ & $49.0 \pm 7.51^{\mathrm{a}}$ & $447 \pm 8.03^{\mathrm{a}}$ & $7800 \pm 0300^{a}$ \\
\hline & & 25 & $3.79 \pm 0.29^{b}$ & $28.2 \pm 5.90^{b}$ & $16.4 \pm 3.06^{\mathrm{a}}$ & $4.96 \pm 0.29^{a}$ & $40.4 \pm 4.37^{\mathrm{a}}$ & $442 \pm 6.28^{a}$ & $6300 \pm 1200^{a}$ \\
\hline & & 50 & $3.78 \pm 0.83^{b}$ & $28.7 \pm 4.45^{b}$ & $18.7 \pm 1.96^{\mathrm{a}}$ & $585 \pm 1.52^{\mathrm{a}}$ & $38.7 \pm 2.80^{\mathrm{a}}$ & $452 \pm 5.53^{a}$ & $7400 \pm 1000^{a}$ \\
\hline & & 75 & $6.69 \pm 2.31^{\mathrm{ab}}$ & $30.8 \pm 2.47^{b}$ & $21.6 \pm 1.21^{\mathrm{a}}$ & $5.13 \pm 0.66^{a}$ & $34.6 \pm 3.04^{a}$ & $446 \pm 11.5^{\mathrm{a}}$ & $7700 \pm 2000^{a}$ \\
\hline & & 100 & $9.44 \pm 2.67^{\mathrm{a}}$ & $39.0 \pm 6.26^{a}$ & $21.5 \pm 1.32^{a}$ & $5.78 \pm 0.75^{a}$ & $35.6 \pm 6.76^{a}$ & $454 \pm 3.17^{a}$ & $9000 \pm 0700^{a}$ \\
\hline & \multirow{5}{*}{$\begin{array}{l}0_{\mathscr{N}}^{\infty} \\
\stackrel{\mathbb{Z}}{Z} \\
Z\end{array}$} & Control & $2.11 \pm 0.25^{c}$ & $44.6 \pm 7.53^{a}$ & $22.4 \pm 1.56^{\mathrm{a}}$ & $5.42 \pm 0.62^{\mathrm{a}}$ & $49.0 \pm 7.51^{\mathrm{a}}$ & $447 \pm 8.03^{\mathrm{a}}$ & $7800 \pm 300^{a b}$ \\
\hline & & 25 & $4.00 \pm 1.50^{b}$ & $34.5 \pm 6.99^{\mathrm{a}}$ & $19.5 \pm 1.45^{\mathrm{a}}$ & $5.77 \pm 0.31^{\mathrm{a}}$ & $35.1 \pm 0.13^{\mathrm{a}}$ & $459 \pm 6.06^{\mathrm{a}}$ & $6600 \pm 1100^{b}$ \\
\hline & & 50 & $9.01 \pm 1.52^{a b}$ & $37.6 \pm 5.05^{\mathrm{a}}$ & $20.4 \pm 0.46^{\mathrm{a}}$ & $5.98 \pm 0.82^{a}$ & $29.9 \pm 3.23^{a}$ & $452 \pm 8.31^{\mathrm{a}}$ & $9800 \pm 500^{a}$ \\
\hline & & 75 & $14.2 \pm 5.65^{\mathrm{a}}$ & $32.2 \pm 2.79^{a}$ & $17.7 \pm 2.41^{\mathrm{a}}$ & $5.70 \pm 0.55^{a}$ & $32.0 \pm 3.34^{\mathrm{a}}$ & $454 \pm 4.45^{\mathrm{a}}$ & $8300 \pm 1600^{a b}$ \\
\hline & & 100 & $17.7 \pm 0.71^{\mathrm{a}}$ & $28.5 \pm 0.92^{b}$ & $19.2 \pm 2.15^{\mathrm{a}}$ & $5.24 \pm 0.34^{\mathrm{a}}$ & $35.0 \pm 4.02^{\mathrm{a}}$ & $457 \pm 5.34^{\mathrm{a}}$ & $7300 \pm 200 \mathrm{ab}$ \\
\hline
\end{tabular}

Different letters within the same column, cultivar and treatment indicate significant differences $(p \leq 0.05)$. Average values are expressed in $\mathrm{mg} \mathrm{kg}^{-1} \pm$ standard deviation $(n=3)$. 
Table 3. Selenium, zinc, iron, copper, calcium, magnesium and potassium concentrations in the white grains of $O$. sativa cultivars.

\begin{tabular}{|c|c|c|c|c|c|c|c|c|c|}
\hline & $\begin{array}{l}\text { Trea } \\
\text { (g S }\end{array}$ & -1) & Se & $\mathrm{Zn}$ & $\mathrm{Fe}$ & $\mathrm{Cu}$ & $\mathrm{Ca}$ & Mg & $\mathbf{K}$ \\
\hline \multirow{10}{*}{$\frac{0}{0}$} & \multirow{5}{*}{$\begin{array}{l}\overbrace{\mathbb{N}}^{+} \\
\text {} \\
\widetilde{Z}\end{array}$} & Control & $\begin{array}{c}2.06 \pm 0.33^{c} \\
(+21.9 \%)\end{array}$ & $\begin{array}{c}32.5 \pm 8.77^{\mathrm{a}} \\
(30.8 \%)\end{array}$ & $\begin{array}{c}9.01 \pm 2.47^{\mathrm{a}} \\
(74.2 \%)\end{array}$ & $\begin{array}{c}3.84 \pm 0.49^{a} \\
\quad(25.1 \%)\end{array}$ & $\begin{array}{c}14.1 \pm 1.34^{\mathrm{a}} \\
(67.9 \%)\end{array}$ & $\begin{array}{c}329 \pm 27.4^{\mathrm{a}} \\
(25.7 \%)\end{array}$ & $\begin{array}{c}1700 \pm 100^{\mathrm{a}} \\
\quad(73.0 \%)\end{array}$ \\
\hline & & 25 & $\begin{array}{l}3.08 \pm 0.73^{b c} \\
\quad(+15.8 \%)\end{array}$ & $\begin{array}{c}24.4 \pm 4.01^{\mathrm{a}} \\
\quad(32.2 \%)\end{array}$ & $\begin{array}{c}7.85 \pm 2.06^{\mathrm{a}} \\
(77.6 \%)\end{array}$ & $\begin{array}{c}4.19 \pm 0.22 \mathrm{a} \\
\quad(13.6 \%)\end{array}$ & $\begin{array}{c}23.0 \pm 2.64^{\mathrm{a}} \\
(45.8 \%)\end{array}$ & $\begin{array}{c}309 \pm 8.43^{\mathrm{a}} \\
(31.0 \%)\end{array}$ & $\begin{array}{c}1900 \pm 300 \mathrm{a} \\
(70.3 \%)\end{array}$ \\
\hline & & 50 & $\begin{array}{c}4.90 \pm 2.14^{\mathrm{ab}} \\
(20.7 \%)\end{array}$ & $\begin{array}{c}21.6 \pm 3.40^{\mathrm{a}} \\
(19.4 \%)\end{array}$ & $\begin{array}{c}8.66 \pm 2.07^{\mathrm{a}} \\
(77.5 \%)\end{array}$ & $\begin{array}{c}4.05 \pm 0.54^{\mathrm{a}} \\
(24.3 \%)\end{array}$ & $\begin{array}{c}21.3 \pm 5.04^{\mathrm{a}} \\
(32.8 \%)\end{array}$ & $\begin{array}{c}238 \pm 27.1^{\mathrm{a}} \\
\quad(46.5 \%)\end{array}$ & $\begin{array}{c}1600 \pm 300^{\mathrm{a}} \\
(81.9 \%)\end{array}$ \\
\hline & & 75 & $\begin{array}{c}5.59 \pm 0.75^{a b} \\
(7.76 \%)\end{array}$ & $\begin{array}{c}18.3 \pm 1.23^{a} \\
(39.6 \%)\end{array}$ & $\begin{array}{c}8.63 \pm 1.74^{\mathrm{a}} \\
\quad(75.3 \%)\end{array}$ & $\begin{array}{c}4.02 \pm 0.08^{\mathrm{a}} \\
\quad(22.5 \%)\end{array}$ & $\begin{array}{c}15.4 \pm 1.47^{\mathrm{a}} \\
\quad(43.2 \%)\end{array}$ & $\begin{array}{c}295 \pm 26.9^{\mathrm{a}} \\
(29.4 \%)\end{array}$ & $\begin{array}{c}2200 \pm 200^{\mathrm{a}} \\
(73.7 \%)\end{array}$ \\
\hline & & 100 & $\begin{array}{c}8.22 \text { 土 } 3.07^{\mathrm{a}} \\
\quad(+1.5 \%)\end{array}$ & $\begin{array}{c}22.3 \pm 5.16^{\mathrm{a}} \\
(27.4 \%)\end{array}$ & $\begin{array}{c}8.58 \pm 2.33^{\mathrm{a}} \\
(76.7 \%)\end{array}$ & $\begin{array}{c}4.29 \pm 0.16^{\mathrm{a}} \\
(27.8 \%)\end{array}$ & $\begin{array}{c}10.7 \pm 0.46^{\mathrm{a}} \\
(65.4 \%)\end{array}$ & $\begin{array}{c}286 \pm 32.6^{b} \\
(31.1 \%)\end{array}$ & $\begin{array}{c}2000 \pm 500^{\mathrm{a}} \\
(76.6 \%)\end{array}$ \\
\hline & \multirow{5}{*}{$\begin{array}{l}0_{\mathbb{N}}^{\infty} \\
\text { స } \\
\text { Z }\end{array}$} & Control & $\begin{array}{c}2.06 \pm 0.33^{c} \\
(+21.9 \%)\end{array}$ & $\begin{array}{c}32.5 \pm 8.77^{\mathrm{a}} \\
(30.8 \%)\end{array}$ & $\begin{array}{c}9.01 \pm 2.47^{\mathrm{a}} \\
(74.2 \%)\end{array}$ & $\begin{array}{c}3.84 \pm 0.49^{\mathrm{a}} \\
(25.1 \%)\end{array}$ & $\begin{array}{c}14.1 \pm 1.34^{\mathrm{a}} \\
(67.9 \%)\end{array}$ & $\begin{array}{c}329 \pm 27.4^{\mathrm{a}} \\
(25.7 \%)\end{array}$ & $\begin{array}{c}1700 \pm 100^{a} \\
(73.0 \%)\end{array}$ \\
\hline & & 25 & $\begin{array}{c}4.07 \pm 0.50 \mathrm{ab} \\
\quad(31.2 \%)\end{array}$ & $\begin{array}{c}22.4 \pm 3.79^{\mathrm{a}} \\
(13.8 \%)\end{array}$ & $\begin{array}{c}11.0 \pm 1.63^{\mathrm{a}} \\
(64.5 \%)\end{array}$ & $\begin{array}{c}4.00 \pm 0.03^{\mathrm{a}} \\
(25.1 \%)\end{array}$ & $\begin{array}{c}10.5 \pm 2.80^{\mathrm{a}} \\
(73.8 \%)\end{array}$ & $\begin{array}{c}254 \pm 18.2^{b} \\
(42.3 \%)\end{array}$ & $\begin{array}{c}1900 \pm 600^{\mathrm{a}} \\
(80.2 \%)\end{array}$ \\
\hline & & 50 & $\begin{array}{c}5.36 \pm 2.37 \mathrm{ab} \\
(29.0 \%)\end{array}$ & $\begin{array}{c}18.9 \pm 1.13^{\mathrm{a}} \\
(42.7 \%)\end{array}$ & $\begin{array}{c}8.71 \pm 1.66^{\mathrm{a}} \\
\quad(78.0 \%)\end{array}$ & $\begin{array}{c}4.24 \pm 0.29 \\
\quad(20.0 \%)\end{array}$ & $\begin{array}{c}15.4 \pm 2.33^{\mathrm{a}} \\
(70.9 \%)\end{array}$ & $\begin{array}{c}283 \pm 13.1 \mathrm{ab} \\
\quad(37.0 \%)\end{array}$ & $\begin{array}{c}1900 \pm 100^{\mathrm{a}} \\
(78.5 \%)\end{array}$ \\
\hline & & 75 & $\begin{array}{c}10.4 \pm 3.29^{\mathrm{a}} \\
\quad(+5.3 \%)\end{array}$ & $\begin{array}{c}20.4 \pm 2.28^{a} \\
(35.4 \%)\end{array}$ & $\begin{array}{c}11.6 \pm 4.60^{\mathrm{a}} \\
(67.6 \%)\end{array}$ & $\begin{array}{c}4.60 \pm 0.46^{\mathrm{a}} \\
(20.6 \%)\end{array}$ & $\begin{array}{c}9.60 \pm 1.78^{\mathrm{a}} \\
(78.8 \%)\end{array}$ & $\begin{array}{c}266 \pm 18.6^{a b} \\
(39.7 \%)\end{array}$ & $\begin{array}{c}1900 \pm 200 \mathrm{a} \\
(78.6 \%)\end{array}$ \\
\hline & & 100 & $\begin{array}{c}8.79 \pm 1.33^{\mathrm{a}} \\
\quad(32.4 \%)\end{array}$ & $\begin{array}{c}19.4 \pm 1.21^{\mathrm{a}} \\
(34.4 \%)\end{array}$ & $\begin{array}{c}8.17 \pm 1.02^{\mathrm{a}} \\
\quad(79.1 \%)\end{array}$ & $\begin{array}{c}3.98 \pm 0.65^{\mathrm{a}} \\
(20.7 \%)\end{array}$ & $\begin{array}{c}10.3 \pm 0.89^{a} \\
(74.1 \%)\end{array}$ & $\begin{array}{c}258 \pm 24.6^{b} \\
(43.4 \%)\end{array}$ & $\begin{array}{c}1700 \pm 400^{\mathrm{a}} \\
(74.8 \%)\end{array}$ \\
\hline \multirow{10}{*}{ 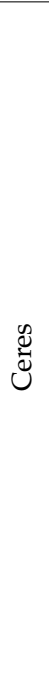 } & \multirow{5}{*}{ 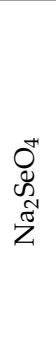 } & Control & $\begin{array}{c}2.34 \pm 0.17^{c} \\
\quad(+16.4 \%)\end{array}$ & $\begin{array}{c}45.8 \pm 1.63^{\mathrm{a}} \\
(34.3 \%)\end{array}$ & $\begin{array}{c}8.02 \pm 1.79^{a} \\
\quad(81.2 \%)\end{array}$ & $\begin{array}{c}4.51 \pm 0.46^{\mathrm{a}} \\
(39.3 \%)\end{array}$ & $\begin{array}{c}18.9 \pm 2.85^{\mathrm{a}} \\
(75.2 \%)\end{array}$ & $\begin{array}{c}293 \pm 8.86^{\mathrm{a}} \\
(30.9 \%)\end{array}$ & $\begin{array}{c}2100 \pm 100^{a} \\
(69.0 \%)\end{array}$ \\
\hline & & 25 & $\begin{array}{c}2.62 \pm 0.38^{c} \\
(36.2 \%)\end{array}$ & $\begin{array}{c}29.2 \pm 3.51^{a} \\
(20.0 \%)\end{array}$ & $\begin{array}{c}7.52 \pm 1.14^{\mathrm{a}} \\
(80.1 \%)\end{array}$ & $\begin{array}{c}4.48 \pm 0.30^{\mathrm{a}} \\
(42.1 \%)\end{array}$ & $\begin{array}{c}13.1 \pm 1.31^{\mathrm{a}} \\
(77.8 \%)\end{array}$ & $\begin{array}{c}304 \pm 9.59^{\mathrm{a}} \\
(25.5 \%)\end{array}$ & $\begin{array}{c}2100 \pm 100^{\mathrm{a}} \\
(75.9 \%)\end{array}$ \\
\hline & & 50 & $\begin{array}{l}3.72 \pm 0.41^{\mathrm{a}} \\
\quad(34.4 \%)\end{array}$ & $\begin{array}{c}25.5 \pm 1.76^{\mathrm{a}} \\
(24.1 \%)\end{array}$ & $\begin{array}{c}7.93 \pm 1.63^{\mathrm{a}} \\
(80.2 \%)\end{array}$ & $\begin{array}{c}4.48 \pm 0.12^{\mathrm{a}} \\
(31.1 \%)\end{array}$ & $\begin{array}{c}17.1 \pm 2.71 \mathrm{a} \\
(66.5 \%)\end{array}$ & $\begin{array}{c}308 \pm 8.49^{\mathrm{a}} \\
(32.0 \%)\end{array}$ & $\begin{array}{c}1800 \pm 400 \mathrm{a} \\
(70.2 \%)\end{array}$ \\
\hline & & 75 & $\begin{array}{c}3.76 \pm 1.14^{\mathrm{a}} \\
\quad(56.6 \%)\end{array}$ & $\begin{array}{c}23.1 \pm 3.46^{\mathrm{a}} \\
(26.4 \%)\end{array}$ & $\begin{array}{c}10.7 \pm 2.07^{\mathrm{a}} \\
(75.5 \%)\end{array}$ & $\begin{array}{c}4.01 \pm 0.84^{\mathrm{a}} \\
(38.6 \%)\end{array}$ & $\begin{array}{c}15.9 \pm 1.68^{\mathrm{a}} \\
(72.2 \%)\end{array}$ & $\begin{array}{c}301 \pm 11.7^{\mathrm{a}} \\
(28.0 \%)\end{array}$ & $\begin{array}{c}2000 \pm 600^{a} \\
(63.8 \%)\end{array}$ \\
\hline & & 100 & $\begin{array}{c}4.30 \pm 1.00^{\mathrm{a}} \\
(62.9 \%)\end{array}$ & $\begin{array}{c}29.5 \pm 2.71^{\mathrm{a}} \\
(40.2 \%)\end{array}$ & $\begin{array}{c}8.45 \pm 1.36^{a} \\
(83.1 \%)\end{array}$ & $\begin{array}{c}4.19 \pm 0.40^{\mathrm{a}} \\
(41.0 \%)\end{array}$ & $\begin{array}{c}15.2 \pm 3.02^{\mathrm{a}} \\
(77.6 \%)\end{array}$ & $\begin{array}{c}264 \pm 10.1^{b} \\
\quad(37.0 \%)\end{array}$ & $\begin{array}{c}1900 \pm 200^{a} \\
(72.7 \%)\end{array}$ \\
\hline & \multirow{5}{*}{ 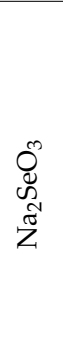 } & Control & $\begin{array}{l}2.34 \pm 0.17^{c} \\
(+16.4 \%)\end{array}$ & $\begin{array}{c}45.8 \pm 1.63^{\mathrm{a}} \\
(34.3 \%)\end{array}$ & $\begin{array}{c}8.02 \pm 1.79^{a} \\
\quad(81.2 \%)\end{array}$ & $\begin{array}{c}4.51 \pm 0.46^{\mathrm{a}} \\
(39.3 \%)\end{array}$ & $\begin{array}{c}18.9 \pm 2.85^{\mathrm{a}} \\
(75.2 \%)\end{array}$ & $\begin{array}{c}293 \pm 8.86^{a} \\
(30.9 \%)\end{array}$ & $\begin{array}{c}2100 \pm 1^{\mathrm{ab}} \\
(69.0 \%)\end{array}$ \\
\hline & & 25 & $\begin{array}{c}3.88 \pm 1.13^{b} \\
(38.4 \%)\end{array}$ & $\begin{array}{c}21.9 \pm 2.22 \mathrm{a} \\
(44.1 \%)\end{array}$ & $\begin{array}{c}8.31 \pm 2.07^{\mathrm{a}} \\
\quad(83.7 \%)\end{array}$ & $\begin{array}{c}4.03 \pm 0.10^{\mathrm{a}} \\
(45.8 \%)\end{array}$ & $\begin{array}{c}18.7 \pm 2.45^{\mathrm{a}} \\
(53.9 \%)\end{array}$ & $\begin{array}{c}242 \pm 11.3^{b} \\
\quad(44.6 \%)\end{array}$ & $\begin{array}{c}1600 \pm 200^{b} \\
(81.1 \%)\end{array}$ \\
\hline & & 50 & $\begin{array}{c}6.09 \pm 1.55^{\mathrm{ab}} \\
(48.4 \%)\end{array}$ & $\begin{array}{c}21.9 \pm 1.36^{a} \\
(40.3 \%)\end{array}$ & $\begin{array}{c}6.45 \pm 0.84^{\mathrm{a}} \\
\quad(84.0 \%)\end{array}$ & $\begin{array}{c}4.13 \pm 0.36^{\mathrm{a}} \\
(32.4 \%)\end{array}$ & $\begin{array}{c}15.4 \pm 2.43^{\mathrm{a}} \\
(72.8 \%)\end{array}$ & $\begin{array}{c}267 \pm 8.94^{\mathrm{a}} \\
\quad(41.6 \%)\end{array}$ & $\begin{array}{c}1800 \pm 400^{b} \\
(71.5 \%)\end{array}$ \\
\hline & & 75 & $\begin{array}{c}9.47 \pm 2.68^{\mathrm{a}} \\
(8.05 \%)\end{array}$ & $\begin{array}{c}24.2 \pm 3.12^{\mathrm{a}} \\
(27.5 \%)\end{array}$ & $\begin{array}{c}5.93 \pm 1.12^{\mathrm{a}} \\
\quad(88.1 \%)\end{array}$ & $\begin{array}{c}4.75 \pm 0.76^{\mathrm{a}} \\
(17.4 \%)\end{array}$ & $\begin{array}{c}23.9 \pm 2.66^{\mathrm{a}} \\
(58.6 \%)\end{array}$ & $\begin{array}{c}276 \pm 10.3^{\mathrm{a}} \\
\quad(35.7 \%)\end{array}$ & $\begin{array}{c}2800 \pm 300^{\mathrm{a}} \\
\quad(54.0 \%)\end{array}$ \\
\hline & & 100 & $\begin{array}{l}11.0 \pm 1.51^{\mathrm{a}} \\
\quad(13.4 \%)\end{array}$ & $\begin{array}{c}26.2 \pm 5.85^{\mathrm{a}} \\
(31.0 \%)\end{array}$ & $\begin{array}{c}6.15 \pm 2.43^{\mathrm{a}} \\
(86.4 \%)\end{array}$ & $\begin{array}{c}4.62 \pm 0.37^{\mathrm{a}} \\
\quad(22.9 \%)\end{array}$ & $\begin{array}{c}11.8 \pm 0.14^{\mathrm{a}} \\
(79.8 \%)\end{array}$ & $\begin{array}{l}224 \pm 12.2^{c} \\
\quad(49.5 \%)\end{array}$ & $\begin{array}{c}1700 \pm 100^{b} \\
(75.0 \%)\end{array}$ \\
\hline
\end{tabular}

Different letters within the same column, cultivar and treatment indicate significant differences $(p \leq 0.05)$. Average values are expressed in $\mathrm{mg} \mathrm{kg}^{-1} \pm$ standard deviation $(n=3)$; data between brackets indicate the percent loss by comparison with rough grains. In some few cases an enrichment was observed, which is described by the signal + .

Regarding the Ariete cultivar we did not find, in general, a pronounced decrease in Se concentrations throughout the processing phase, in selenate treated plants, while the loss in selenite treated plants range between $29 \%$ and $32.4 \%$ (Table 3). In two particular cases a small Se enrichment was observed in polished grains-paddy grains derived from plants treated with $100 \mathrm{~g}$ Se.ha ${ }^{-1}$ selenate and $75 \mathrm{~g}$ Se.ha ${ }^{-1}$ selenite, which contained 8.10 and 9.88 $\mathrm{mg} \mathrm{kg}^{-1} \mathrm{Se}$, respectively, whereas the polished grains with the same treatments contained 8.22 and $10.4 \mathrm{mg} \mathrm{kg}^{-1} \mathrm{Se}$, respectively, with the correspondent enrichment of $1.5 \%$ and $5.3 \%$ (Tables 1 and 3), enhancing the great variability of Se concentrations. A similar situation occurs in control plants in polished grains of both cultivars, with enrichments of Se around $20 \%$. This fact is mainly attributed to the very low concentrations of Se (circa. $2 \mathrm{mg} . \mathrm{kg}^{-1}$ ) whose variability induces those increments. 


\subsection{Macro and Micronutrient Quantification in Rice Grains \\ 2.3.1. Paddy Rice}

Regarding the accumulation of $\mathrm{Cu}$ as a function of the different concentrations of $\mathrm{Se}$, as selenite and selenate, no major variations were detected as a result of the different treatments, regardless of the cultivars. The average values were not significantly different at the 0.05 significance level. Nevertheless, Ceres cultivar accumulated more $\mathrm{Cu}$ than Ariete cultivar. The minimum and maximum concentrations range between 4.85 and 5.94 in Ariete while in Ceres they were between 5.75 and $7.74 \mathrm{mg} \mathrm{kg}^{-1}$ (Table 1).

Regarding $\mathrm{Zn}$ and $\mathrm{Fe}$, it was noted that in Ariete, the Fe levels were similar, ranging between 31.0 and $39.6 \mathrm{mg} \mathrm{kg}^{-1}$, when considering the whole treatments and different types of application, while in Ceres cultivar these levels range between 37.8 and $51.0 \mathrm{mg} \mathrm{kg}^{-1}$, regardless of the treatment used. Zinc was the element clearly affected by the treatments with $\mathrm{Se}$-control grains exhibited approximately 50 and $70 \mathrm{mg} \mathrm{kg}^{-1}$ for Ariete and Ceres, respectively. When the higher concentrations of Se were applied (75 g and $100 \mathrm{~g}$ Se.ha ${ }^{-1}$ of both selenate and selenite), the decrease in $\mathrm{Zn}$ in Ariete grains was ca. $36 \%$, while in Ceres the reduction range was between $29 \%$ and $54 \%$ (Table 1 ).

Regarding $\mathrm{Ca}$, the concentrations in the different grains are not significantly different $(p \leq 0.05)$, although the values observed in the Ariete cultivar treated with selenite are higher than those observed for selenate. Conversely, in Ceres cultivar the higher concentrations were noticed for selenate (Table 2). The concentrations of $\mathrm{Mg}$ in the paddy grains range between 408 and $457 \mathrm{mg} \mathrm{kg}^{-1}$ regardless of the cultivars, Se species and concentrations used, thus indicating a narrow variation. The concentrations of $\mathrm{K}$ in the paddy grains of Ariete cultivar range between 6300 and $9400 \mathrm{mg} \mathrm{kg}^{-1}$, while in Ceres cultivar they range between 5500 and $8700 \mathrm{mg} \mathrm{kg}^{-1}$. In general, the treatments did not seem to influence the $\mathrm{K}$ concentration in grain by the cultivars, although in Ariete the control grains presented generally the lowest levels (Table 1).

\subsubsection{Brown Rice}

In general, the concentrations of $\mathrm{Fe}$ and $\mathrm{Cu}$ did not vary significantly as a result of the different treatments (selenite and selenate) and concentrations applied and regardless of the cultivars (Table 2). Regarding Zn, a strong decrease was observed in Ariete cultivar, whose treated grains contained $\mathrm{Zn}$ levels ranging between 24.9 and $28.9 \mathrm{mg} \mathrm{kg}^{-1}$ when selenate was applied, and 26.1 and $28.3 \mathrm{mg} \mathrm{kg}^{-1}$ when selenite was used-control grains presented $29.5 \mathrm{mg} \mathrm{kg}^{-1}$ (Table 2). In Ceres cultivar the $\mathrm{Zn}$ concentrations ranged between 28.2 and $39.0 \mathrm{mg} \mathrm{kg}^{-1}$ (selenate) and 28.5 and $37.6 \mathrm{mg} \mathrm{kg}^{-1}$ (selenite), whose values are closer to the control one which is $44.6 \mathrm{mg} \mathrm{kg}^{-1}$. The Ca concentrations in the grains exhibited a great variation regardless of the treatments (selenite vs. selenate) and concentrations used; thus, we cannot establish a trend regarding this macronutrient, although the mean values in Ceres were clearly higher than those observed for Ariete (Table 2).

The $\mathrm{Mg}$ concentrations in the grains were close regardless of the cultivars, type of Se fertilizer and concentration used. In Ariete cultivar the concentrations range between 425 and $454 \mathrm{mg} \mathrm{kg}^{-1}$ regardless of the treatments, while in Ceres the range is smaller, i.e., between 442 and $459 \mathrm{mg} \mathrm{kg}^{-1}$ (Table 2). No significant differences were observed $(p \leq 0.05)$ in the concentrations of $\mathrm{K}$ in both Se treated Ariete and Ceres cultivars. The control grains exhibited the lowest K levels in Ariete, but not in Ceres cultivar (Table 2).

\subsubsection{White Rice}

In polished rice, the concentrations of $\mathrm{Fe}$ and $\mathrm{Cu}$ the grains were not significantly different at the 0.05 significance level, regardless of the cultivars, type of treatment and concentrations used (Table 3). Similarly to paddy and brown grains, the $\mathrm{Zn}$ levels in control grains were always higher than levels observed in the different treatments. Nevertheless, the gap was not as large as that which occurred for paddy and brown grains. For example, in Ariete cultivar grain $\mathrm{Zn}$ concentrations range between 18.3 and $24.4 \mathrm{mg} \mathrm{kg}^{-1}$ regardless of the treatment and concentration used, while in Ceres cultivar this range is between is 21.9 
and $29.5 \mathrm{mg} \mathrm{kg}^{-1}$. Control grains of Ariete and Ceres contained an average concentration of $32.5 \mathrm{mg} \mathrm{kg}^{-1}$ and $45.8 \mathrm{mg} \mathrm{kg}^{-1}$, respectively (Table 3).

The Ca levels are low in both cultivars, seldom exceeding $20.0 \mathrm{mg} \mathrm{kg}^{-1}$. Additionally, they exhibited a great variability within treatments. The $\mathrm{K}$ concentrations in polished grains range between 1600 and $2200 \mathrm{mg} \mathrm{kg}^{-1}$ and 1600 and $2800 \mathrm{mg} \mathrm{kg}^{-1}$, for Ariete and Ceres cultivars, respectively, while control values are $1700 \mathrm{mg} \mathrm{kg}^{-1}$ for Ariete and $2100 \mathrm{mg} \mathrm{kg}^{-1}$ for Ceres. Despite the highest $\mathrm{Mg}$ levels being observed in control grains, the concentrations in general are not significantly different $(p \leq 0.05)$ (Table 3$)$.

\subsubsection{Comparison between Elemental Levels in Paddy and White Rice Grains}

In white rice, the milling and polishing processes remove nutrients; thus, it is interesting to compare final composition in terms of several micro and macronutrients vis a vis the composition observed in paddy rice, i.e., the whole rice grain with the hulls. This analysis is focused on the losses of both cultivars (Ariete and Ceres) regardless of treatments with selenite and selenate, or even control plants. In Ariete, the minimum losses were observed for $\mathrm{Cu}$ and $\mathrm{Zn}$ with percent values ranging between $13.6 \%$ and $27.8 \%$ for $\mathrm{Cu}$ and $13.8 \%$ and $42.7 \%$ for $\mathrm{Zn}$. In the case of $\mathrm{Cu}$, if we discount the lowest value a certain constancy was observed regardless of the cultivars with values ranging between $20 \%$ and $27.8 \%$. In Ceres, the losses for the same elements were more pronounced ranging between $17.4 \%$ and $45.8 \%$ for $\mathrm{Cu}$ and $20 \%$ and $44.1 \%$ for $\mathrm{Zn}$. In the case of selenate treated plants the loss of $\mathrm{Cu}$ varies between $31.1 \%$ and $42.1 \%$ while in selenite treated plants between $17.4 \%$ and $45.8 \%$, thus exhibiting a large variability (Table 3). The loss of Fe in white grains was drastic with levels, in the overwhelming majority of the cases, below $10 \mathrm{mg} \mathrm{kg}^{-1}$ with correspondent losses ranging between $64.5 \%$ and $79.1 \%$ for Ariete and $75.5 \%$ and $88.1 \%$ for Ceres. Regarding Zn, a decrease in the concentration was noted when polished grains were analyzed, although this trend was not so pronounced as that which was verified for Fe (Table 3).

Regarding macronutrients, remarkable losses were noted for Ca with a narrow variability in Ariete cultivar treated with selenite (67.9-78.8\%) and Ceres treated with selenate (66.5-77.8\%). Conversely, selenate treated plants from Ariete and selenite treated plants from Ceres exhibited a larger variation with values ranging between $32.8 \%$ and $67.9 \%$ for Ariete and $53.9 \%$ and $79.8 \%$ for Ceres. The losses of $\mathrm{K}$ associated with polished grains were generally above $70 \%$, for both cultivars, while the losses of $\mathrm{Mg}$ range between $25.5 \%$ and $49.5 \%$, regardless of cultivars, Se species and concentrations used. Similarly to the other elements, losses of Se also occur, although showing a great variability-between $8.05 \%$ and $62.9 \%$ in Ceres, and $32.4 \%$ and an increment of $21.9 \%$ in Ariete (Table 3).

\subsection{Colour Analysis}

In paddy rice, $\mathrm{L}$ values are so close that no significant differences can be observed $(p \leq 0.05)$, a finding that is extensive in brown and white grains. Nevertheless, the L levels in Ceres cultivar are a little bit smaller than the corresponding values of Ariete.

Regarding brown rice, the value of $\mathrm{L}$ in Ariete and Ceres cultivars are almost identical regardless of the type of application (selenate, selenite) and concentrations used (Table 4). A similar situation occurred with polished rice although it can be stressed that $L$ values show an increasing trend from paddy to white grains. The $\mathrm{a}^{*}$ ( red-green transitions) positive values in paddy and brown rice are not significantly different $(p \leq 0.05)$, regardless of the cultivars and Se concentrations, while negative values were observed for polished rice $(p \leq 0.05)$ - in Ariete cultivar these negative values range between -0.60 and -0.88 , while in the Ceres cultivar the range is between -0.81 and -1.12 . In paddy rice the $b^{*}$ (yellowblue transitions) are not significantly different $(p \leq 0.05)$, regardless of the cultivars and different Se concentrations used, although $b^{*}$ values in Ceres cultivar are a little bit higher than similar values derived from Ariete (Table 4).

When brown rice is considered we saw a small decrease in $b^{*}$ values in both cultivars followed by a strong reduction in $\mathrm{b}^{*}$ values in white rice $(>50 \%)$, which is probably related with industrial processes such as dehusking and whitening (Table 4). 
Table 4. Color parameters of the paddy, brown and white rice grains of $O$. sativa, cultivars.

\begin{tabular}{|c|c|c|c|c|c|c|c|c|c|c|}
\hline & \multirow{2}{*}{$\begin{array}{l}\text { Treatments } \\
\left(\mathrm{g} \mathrm{Se} \mathrm{ha}^{-1}\right)\end{array}$} & \multicolumn{3}{|c|}{ Paddy Rice } & \multicolumn{3}{|c|}{ Brown Rice } & \multicolumn{3}{|c|}{ White Rice } \\
\hline & & $\mathbf{L}$ & $a^{*}$ & $\mathbf{b}^{*}$ & $\mathbf{L}$ & $a^{*}$ & $\mathbf{b}^{*}$ & $\mathbf{L}$ & $a^{*}$ & $\mathbf{b}^{*}$ \\
\hline & \multicolumn{10}{|c|}{$\mathrm{Na}_{2} \mathrm{SeO}_{4}$} \\
\hline \multirow{11}{*}{. } & Control & $59.8 \pm 2.23^{a}$ & $5.57 \pm 1.44^{\mathrm{a}}$ & $27.7 \pm 3.35^{\mathrm{a}}$ & $63.5 \pm 2.35^{a}$ & $3.48 \pm 0.44^{\mathrm{a}}$ & $23.1 \pm 0.18^{\mathrm{a}}$ & $73.6 \pm 1.11^{a}$ & $-0.80 \pm 0.24^{\mathrm{a}}$ & $9.52 \pm 0.54^{\mathrm{a}}$ \\
\hline & 25 & $58.6 \pm 0.81^{\mathrm{a}}$ & $5.97 \pm 1.20^{\mathrm{a}}$ & $27.9 \pm 3.19^{\mathrm{a}}$ & $63.4 \pm 1.52^{\mathrm{a}}$ & $2.81 \pm 0.22^{a}$ & $22.1 \pm 0.95^{\mathrm{a}}$ & $74.2 \pm 0.32^{\mathrm{a}}$ & $-0.86 \pm 0.13^{a}$ & $9.25 \pm 0.70^{a}$ \\
\hline & 50 & $59.3 \pm 2.14^{\mathrm{a}}$ & $5.51 \pm 1.52^{a}$ & $26.6 \pm 3.31^{a}$ & $62.6 \pm 3.05^{\mathrm{a}}$ & $3.50 \pm 0.96^{\mathrm{a}}$ & $23.6 \pm 1.51^{\mathrm{a}}$ & $73.5 \pm 1.40^{\mathrm{a}}$ & $-0.78 \pm 0.12^{a}$ & $9.73 \pm 1.07^{a}$ \\
\hline & 75 & $58.9 \pm 1.81^{a}$ & $5.78 \pm 1.56^{\mathrm{a}}$ & $27.6 \pm 3.97^{a}$ & $62.5 \pm 2.75^{a}$ & $3.20 \pm 0.43^{a}$ & $22.8 \pm 0.60^{a}$ & $74.0 \pm 1.52^{\mathrm{a}}$ & $-0.80 \pm 0.18^{a}$ & $9.51 \pm 0.38^{a}$ \\
\hline & 100 & $59.6 \pm 3.33^{a}$ & $6.07 \pm 0.98^{a}$ & $28.1 \pm 2.48^{\mathrm{a}}$ & $63.0 \pm 2.00^{\mathrm{a}}$ & $3.16 \pm 0.48^{\mathrm{a}}$ & $23.3 \pm 0.58^{a}$ & $72.1 \pm 1.66^{\mathrm{a}}$ & $-0.66 \pm 0.10^{\mathrm{a}}$ & $10.1 \pm 1.01^{\mathrm{a}}$ \\
\hline & \multicolumn{10}{|c|}{$\mathrm{Na}_{2} \mathrm{SeO}_{3}$} \\
\hline & Control & $59.0 \pm 2.17^{a}$ & $5.78 \pm 1.35^{\mathrm{a}}$ & $27.3 \pm 2.87^{a}$ & $63.6 \pm 2.17^{a}$ & $3.45 \pm 0.35^{\mathrm{a}}$ & $23.5 \pm 0.91^{\mathrm{a}}$ & $74.3 \pm 1.12^{\mathrm{a}}$ & $-0.88 \pm 0.15^{\mathrm{a}}$ & $8.78 \pm 0.60^{a}$ \\
\hline & 25 & $59.9 \pm 2.15^{\mathrm{a}}$ & $5.31 \pm 1.71^{a}$ & $27.4 \pm 3.64^{\mathrm{a}}$ & $62.3 \pm 1.08^{a}$ & $3.63 \pm 1.12^{\mathrm{a}}$ & $23.1 \pm 0.87^{\mathrm{a}}$ & $73.9 \pm 2.35^{\mathrm{a}}$ & $-0.60 \pm 0.20^{a}$ & $9.24 \pm 0.65^{a}$ \\
\hline & 50 & $58.0 \pm 2.98^{a}$ & $5.73 \pm 1.89^{a}$ & $27.0 \pm 3.10^{\mathrm{a}}$ & $63.4 \pm 2.22^{\mathrm{a}}$ & $3.10 \pm 0.43^{a}$ & $23.8 \pm 1.04^{\mathrm{a}}$ & $74.5 \pm 0.24^{\mathrm{a}}$ & $-0.82 \pm 0.11^{\mathrm{a}}$ & $9.08 \pm 0.48^{a}$ \\
\hline & 75 & $59.1 \pm 2.10^{a}$ & $5.76 \pm 1.53^{a}$ & $27.5 \pm 2.86^{\mathrm{a}}$ & $64.2 \pm 2.79^{a}$ & $3.13 \pm 0.78^{\mathrm{a}}$ & $23.5 \pm 0.75^{\mathrm{a}}$ & $74.4 \pm 1.23^{\mathrm{a}}$ & $-0.88 \pm 0.11^{\mathrm{a}}$ & $9.12 \pm 0.34^{\mathrm{a}}$ \\
\hline & 100 & $58.4 \pm 2.38^{a}$ & $5.73 \pm 1.90^{\mathrm{a}}$ & $27.2 \pm 3.90^{\mathrm{a}}$ & $64.0 \pm 1.80^{\mathrm{a}}$ & $3.27 \pm 0.56^{\mathrm{a}}$ & $23.8 \pm 0.43^{\mathrm{a}}$ & $73.8 \pm 1.92^{\mathrm{a}}$ & $-0.88 \pm 0.04^{\mathrm{a}}$ & $9.22 \pm 0.40^{\mathrm{a}}$ \\
\hline \multirow{12}{*}{ U⿺辶 } & \multicolumn{10}{|c|}{$\mathrm{Na}_{2} \mathrm{SeO}_{4}$} \\
\hline & Control & $58.6 \pm 1.39^{a}$ & $6.56 \pm 0.32^{a}$ & $32.8 \pm 0.88^{\mathrm{ab}}$ & $62.0 \pm 2.03^{a}$ & $3.57 \pm 0.83^{\mathrm{a}}$ & $22.8 \pm 0.59^{a}$ & $72.1 \pm 1.51^{a}$ & $-1.02 \pm 0.06^{\mathrm{a}}$ & $8.42 \pm 0.47^{a}$ \\
\hline & 25 & $57.5 \pm 0.88^{a}$ & $6.98 \pm 0.76^{\mathrm{a}}$ & $33.2 \pm 1.10^{\mathrm{a}}$ & $63.1 \pm 1.82^{a}$ & $2.85 \pm 1.03^{a}$ & $22.1 \pm 0.65^{a}$ & $74.0 \pm 1.19^{a}$ & $-1.12 \pm 0.11^{\mathrm{a}}$ & $7.59 \pm 0.86^{a}$ \\
\hline & 50 & $58.3 \pm 0.68^{a}$ & $6.82 \pm 0.14^{\mathrm{a}}$ & $33.4 \pm 0.42^{\mathrm{a}}$ & $61.7 \pm 2.32^{a}$ & $2.91 \pm 0.47^{\mathrm{a}}$ & $23.0 \pm 0.50^{\mathrm{a}}$ & $72.4 \pm 0.99^{a}$ & $-0.94 \pm 0.20^{a}$ & $7.61 \pm 1.15^{a}$ \\
\hline & 75 & $58.7 \pm 0.62^{a}$ & $6.60 \pm 0.27^{a}$ & $32.0 \pm 0.52^{\mathrm{ab}}$ & $62.9 \pm 1.76^{a}$ & $3.03 \pm 0.12^{\mathrm{a}}$ & $22.6 \pm 0.49^{\mathrm{a}}$ & $74.3 \pm 0.60^{\mathrm{a}}$ & $-1.01 \pm 0.15^{\mathrm{a}}$ & $7.92 \pm 1.02^{\mathrm{a}}$ \\
\hline & 100 & $56.5 \pm 1.20^{a}$ & $6.36 \pm 0.28^{a}$ & $31.2 \pm 0.43^{\mathrm{b}}$ & $62.4 \pm 2.88^{a}$ & $3.26 \pm 0.57^{\mathrm{a}}$ & $22.7 \pm 0.44^{\mathrm{a}}$ & $73.0 \pm 1.66^{\mathrm{a}}$ & $-1.03 \pm 0.08^{a}$ & $8.18 \pm 0.50^{a}$ \\
\hline & \multicolumn{10}{|c|}{$\mathrm{Na}_{2} \mathrm{SeO}_{3}$} \\
\hline & Control & $57.5 \pm 1.28^{a}$ & $6.09 \pm 0.62^{a}$ & $30.4 \pm 1.00^{\mathrm{a}}$ & $61.8 \pm 0.86^{\mathrm{a}}$ & $3.50 \pm 0.44^{\mathrm{a}}$ & $23.1 \pm 1.53^{a}$ & $72.0 \pm 1.42^{\mathrm{a}}$ & $-1.03 \pm 0.08^{a}$ & $8.17 \pm 1.09^{a}$ \\
\hline & 25 & $57.5 \pm 1.12^{\mathrm{a}}$ & $6.36 \pm 0.27^{a}$ & $31.8 \pm 0.83^{\mathrm{a}}$ & $63.8 \pm 2.85^{a}$ & $2.93 \pm 0.28^{a}$ & $22.7 \pm 0.77^{\mathrm{a}}$ & $72.5 \pm 1.67^{\mathrm{a}}$ & $-0.81 \pm 0.38^{a}$ & $8.13 \pm 1.58^{a}$ \\
\hline & 50 & $57.8 \pm 0.40^{a}$ & $6.29 \pm 0.34^{\mathrm{a}}$ & $31.7 \pm 0.46^{\mathrm{a}}$ & $62.9 \pm 0.97^{a}$ & $3.20 \pm 1.01^{\mathrm{a}}$ & $23.6 \pm 1.35^{\mathrm{a}}$ & $74.7 \pm 0.75^{\mathrm{a}}$ & $-0.98 \pm 0.11^{\mathrm{a}}$ & $8.26 \pm 1.30^{a}$ \\
\hline & 75 & $57.3 \pm 1.47^{\mathrm{a}}$ & $6.98 \pm 0.14^{\mathrm{a}}$ & $31.5 \pm 0.70^{\mathrm{a}}$ & $63.0 \pm 1.81^{a}$ & $3.18 \pm 0.85^{\mathrm{a}}$ & $22.8 \pm 2.06^{\mathrm{a}}$ & $73.0 \pm 1.40^{a}$ & $-1.07 \pm 0.08^{a}$ & $7.96 \pm 0.83^{a}$ \\
\hline & 100 & $56.9 \pm 0.78^{a}$ & $6.51 \pm 0.35^{\mathrm{a}}$ & $31.4 \pm 1.07^{\mathrm{a}}$ & $63.1 \pm 0.38^{a}$ & $2.90 \pm 0.83^{\mathrm{a}}$ & $22.4 \pm 0.50^{\mathrm{a}}$ & $74.2 \pm 0.47^{\mathrm{a}}$ & $-1.01 \pm 0.14^{\mathrm{a}}$ & $8.31 \pm 0.60^{a}$ \\
\hline
\end{tabular}

Different letters indicate significant differences between treatments $\left(\mathrm{Na}_{2} \mathrm{SeO}_{4}\right.$ or $\mathrm{Na}_{2} \mathrm{SeO}_{3}$ ), for each cultivar (single factor ANOVA test, $p \leq 0.05)$. Average values \pm standard error $(n=4)$. Color parameters: $\mathrm{L}^{*}$-lightness; $\mathrm{a}^{*}$-red-green transitions; $\mathrm{b}^{*}$-yellow-blue transitions.

\subsection{Location of Se in Grains}

The location of Se in rice grains was performed on dehusked grains since the longitudinal cut removes the outer layer. The elemental distribution analysis by $\mu$-EDXRF showed that, in Ariete cultivar, Se is mostly homogeneously distributed in the grain (Figure 2) regardless of treatments with sodium selenate or sodium selenite. Nevertheless, selenite seems to be more effective in Se enrichment which is validated by the concentration observed in brown grain-12.1 and $16.7 \mathrm{mg} \mathrm{kg}^{-1}$, for 75 and $100 \mathrm{~g} \mathrm{Se} \mathrm{ha}^{-1}$, respectively.

The Se map of the control grains shows a fairly homogeneous distribution of Se within the grain with somewhat higher values near the bran, albeit with a very low concentration, especially in the Ariete cultivar. In the Ceres cultivar, regarding the treatments with 75 and $100 \mathrm{~g} \mathrm{Se} \mathrm{ha}^{-1}$, the Se distribution seems to favor accumulation in the periphery, perhaps in the bran (Figure 2). 


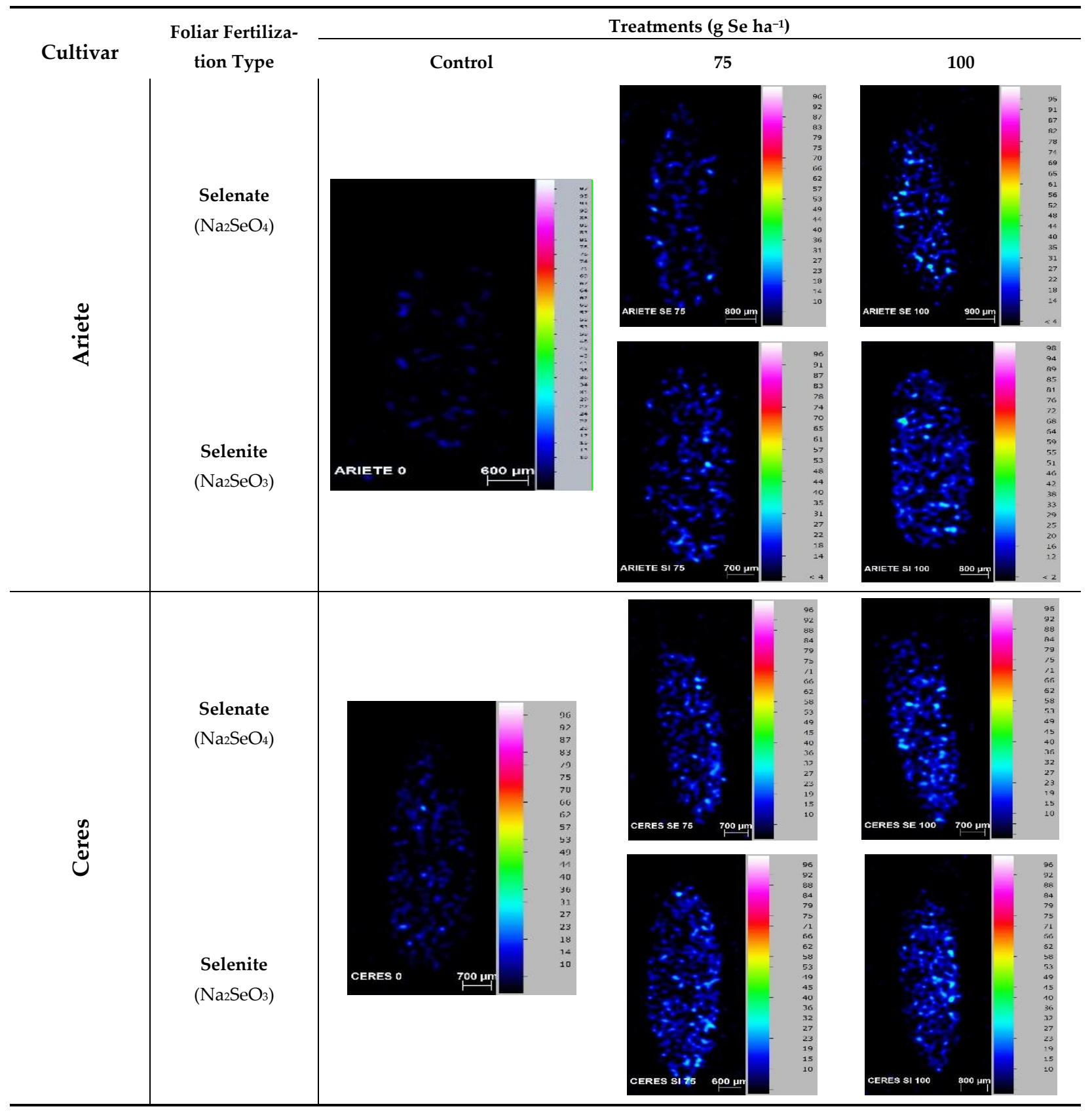

Figure 2. Localization of Se in rice grains of Ariete and Ceres cultivars after foliar spraying with the highest concentrations of sodium selenite and sodium selenate. Control grains did not receive any type of Se enrichment.

\section{Discussion}

After the second application of Se, net photosynthesis $\left(\mathrm{P}_{\mathrm{n}}\right)$ showed to be quite stable in both cultivars, although with significant rises in Ceres at the greatest doses of both Se-forms. On the other hand, $g_{s}$ and $E$ tended to show higher values. This was clearer at the maximal doses of selenite and selenate, particularly in Ariete (Figure 1). Other authors showed that the application of Se in rice fields enhanced photosynthesis by increasing $P_{n}$, $\mathrm{E}$ and the intercellular $\mathrm{CO}_{2}$ concentration $\left(\mathrm{C}_{\mathrm{i}}\right)$. These findings were in line with the rise of the photochemical efficiency of photosystem II $\left(\mathrm{F}_{\mathrm{v}} / \mathrm{F}_{\mathrm{m}}\right)$, and a reduced $\mathrm{F}_{\mathrm{o}}$ [30], thus showing that both leaf gas exchanges and chlorophyll fluorescence analysis can be used to monitoring the photosynthetic functioning of Se-treated rice plants.

At a cellular level, chloroplasts are one of the first target organs of environmental stress [31], leading to changes in photosynthetic rates. However, the addition of adequate 
levels of Se can mitigate some damage at the photosynthetic apparatus [32], and even counteract for expected global warming that will affect grain production, especially in rice (see [19]). When investigating the effects of $\mathrm{Se}\left(0,1,5\right.$ and $\left.25 \mu \mathrm{M} \mathrm{Na}_{2} \mathrm{SeO}_{3}\right)$ in photosynthesis, antioxidative capacity and ion homeostasis in maize under salinity, Jiang et al. [32] showed that Se $(1 \mu \mathrm{M})$ relieved the salt-induced inhibitory effects on the plant growth and development while increasing the net photosynthetic rate and alleviating the damage to chloroplast ultrastructure induced by $\mathrm{NaCl}$. They also showed that $\mathrm{P}_{\mathrm{n}}$ values decrease as [As] increases, while $g_{s}$ remains stable when 1 and $5 \mu \mathrm{M}$ Se are used, decreasing $30 \%$ with the highest Se application.

As stated above, although the $P_{n}$ values in Ariete showed only a marginal increase in Se-treated plants, Ceres presented a significant (although with a maximal increase of ca. $6 \%) \mathrm{P}_{\mathrm{n}}$ rise, thus indicating a somewhat Se stimulating effect at the maximum levels of both Se-forms, which could be positively reflected in greater yields, in line with the higher number of tillers per plant, more grains per panicle, bigger grains and higher yields found in rice plants sprayed with selenite [33,34]. In fact, there are a wealth of reports pointing to beneficial Se impacts in plants, including increase in photosynthesis [35], enhancement of plant growth and development [36], to increased crop yield and quality [37-39].

Notably, in both rice cultivars greater $\mathrm{g}_{\mathrm{s}}$ and $\mathrm{E}$ values were observed in Se-treated plants, particularly at the highest dose of $100 \mathrm{~g} \mathrm{Se} \mathrm{ha}^{-1}$, stronger values were recorded in Ariete. These findings contrast with those observed for maize in which both $g_{s}$ and $E$ values decreased as Se concentration increased [32]. Furthermore, in Ariete the $P_{n}$ and $\mathrm{g}_{\mathrm{s}}$ variation led to a reduction in iWUE by $41 \%$ and $32 \%$ compared to control plants, for the $100 \mathrm{~g}_{\text {-Se.ha }}{ }^{-1}$ selenite and selenate, respectively, whereas in Ceres no significant changes were observed as regards iWUE. Again, our results with rice contrasted with those for Raphanus sativus, where all the treatments with Se (sodium selenate and sodium selenite) and two forms of application (soil and foliar application) resulted in increasing stomatal conductance, transpiratory rate, instantaneous efficiency of water use and intrinsic efficiency of water use when compared with control plants [40], thus denoting a species/cultivar dependent responsiveness to Se fertilization. In fact, the link between ecophysiology data and Se accumulation in the rice grain is crucial to understand whether the impacts at leaf gas exchanges (particularly photosynthesis) are reflected in yield and quality (i.e., Se accumulation). Still, the dose of $100 \mathrm{~g} \mathrm{Se} \cdot \mathrm{ha}^{-1}$ can be applied to the Ariete and Ceres cultivars without compromising the photosynthetic machinery, which is quite promising as regards the maximization of Se absorption.

In general, there was a progressive increase in Se in the paddy grains as the foliar concentrations of Se increased (Table 1) and the highest levels were observed in Ceres cultivar with selenite application, although the literature points out a diversity of results mostly depending on the rice cultivars, type of experiment (field research, pot or hydroponic cultures), Se forms and respective concentrations used, type of fertilization (soil or foliar), and soil and climatic variables when experiments are conducted in open fields.

The Se concentrations in rice with foliar spray of selenite or selenate at the late tillering (LT) or full heading (FH) stages show that, in both stages, selenate was much more effective in grain enrichment than selenite [41]. For example, the concentration in rice grains when selenite was applied was 0.44 and $1.29 \mathrm{mg} \mathrm{kg}^{-1}$ for LT and FH, respectively, whereas for selenate these values were 0.78 and $2.71 \mathrm{mg} \mathrm{kg}^{-1}$, for similar stages. In the same context it was observed that the use of Se under selenite and selenate forms in rice, on both foliar and soil applications, showed interesting and diversified patterns of accumulation [10]. In fact, soil application of selenite pointed out a preferential Se accumulation in roots than in shoots and grain, compared with selenate. Although both forms increased Se grain content, selenate in parallel with soil application are the best choices for maximum enrichment.

Two different cultivars of rice were submitted to foliar fertilization by various concentrations of selenite and selenate $\left(25,50,75\right.$ and $100 \mathrm{~g}$ Se.ha $\left.{ }^{-1}\right)$ at different stages of rice development, i.e., booting, anthesis and milky grain phase. After harvest a 4.9-7.1-fold increase in Se content was observed in grain from plants sprayed with selenate, while a 
5.9-8.4-fold increase was noted for selenite [42]. These findings are in agreement with previous reports using four rice genotypes (Ariete, Albatros, OP1105 and OP1109) in field trials with foliar fertilization ranging between 0 and $300 \mathrm{~g}$ Se.ha ${ }^{-1}$ for sodium selenite and sodium selenate [14]. At the end of the plant cycle, the most prominent results regarding Se accumulation in the grains were achieved with selenite applications without relevant inhibitory effects on yields [14].

Furthermore, the use of selenite fertilizer via foliar application was more effective in Se rice grain accumulation in four different genotypes than selenate, although the highest concentrations of both fertilizers (120 and $180 \mathrm{~g} \mathrm{Se.ha}^{-1}$ ) increased total lipids in all cultivars, mainly oleic, linoleic and palmitic acids [43].

Regarding the effects of selenite and selenate fertilization on the elemental composition of some micro and macronutrients in rice grains, the differences related with the type of application i.e., foliar or via soil, can be stressed once again. For example, in rice, the $\mathrm{Cu}$ and Fe levels in the grains are not significantly different $(p \leq 0.05)$ when soil fertilization occurs at a dose of $0.75 \mathrm{mg} \mathrm{kg}^{-1}$, and regardless of the use of selenate or selenite. Conversely, when foliar fertilization was used at a concentration of $50 \mu \mathrm{m} \mathrm{L}^{-1}$, the highest levels of these elements were always observed for selenate [10]. The same authors point out that the concentrations of $\mathrm{Zn}$ are similar, in general, regardless of the type of fertilization, although the highest value was found via soil fertilization for selenate [10].

Selenium in the form of selenite at a concentration of $150 \mathrm{mg} \mathrm{ha}^{-1}$ and $300 \mathrm{mg} \mathrm{ha}^{-1}$, was used via foliar spraying on two rice cultivars (MAK and IR-87864) in paddy fields of Mozambique and the analysis of the flour derived from the whole grain revealed a small decrease in $\mathrm{Zn}$ flour $\left(9.06 \mathrm{mg} \mathrm{kg}^{-1}\right.$ in the case of 150 Se treatment; $9.11 \mathrm{mg} \mathrm{kg}^{-1}$ with 300 Se treatment) compared with the control $\left(9.79 \mathrm{mg} \mathrm{kg}^{-1}\right)$. Regarding the IR cultivar, the control and plants treated with $150 \mathrm{mg} \mathrm{Se} \mathrm{ha}^{-1}$ contained $12.6 \mathrm{mg} \mathrm{kg}^{-1}$, while plants treated with the double concentration only exhibited $10.6 \mathrm{mg} \mathrm{kg}^{-1}$ [18]. Our rice cultivars show a significant decrease in $\mathrm{Zn}$ content, when treated with both selenite and selenite, although our analysis was performed at grain level (paddy), thus indicating that if flour was obtained the pattern would be the same. The same authors [18] also point out that remarkable decreases in the $\mathrm{Zn}$ content were observed when the flour was obtained from polished grains.

The reduction in values of $a^{*}$ and $b^{*}$ values throughout the grain processing is in agreement with the removal of outer pigment-rich layers, a polished grain with almost starch remaining, although the degree of milling (DOM) and milling time were fundamental in the whole process. Brightness ( $\mathrm{L}^{*}$ value) of the raw rice kernel and rice flour [44] increased until a DOM of approximately $15 \%$ when bran and outer endosperm were removed, which agrees with our trend regarding $L^{*}$ value. They also noted that further milling did not affect rice brightness [44]. Nevertheless, external factors such as post-harvest processes (storage and drying) can influence grain color and should also be considered [45] when performing this type of analysis.

The elemental location within the grain, in particular Se, is important in order to understand its role in the development of the seed [46]. In addition, the knowledge of Se location and speciation is important, because the anti-cancer effects depend on its speciation [47].

Our results show that Se is distributed evenly on the endosperm, although in particular cases a peripheral location was noted, corresponding to the bran (Figure 2). A synchrotron $\mathrm{X}$-ray fluorescence $(\mathrm{XRF})$ analysis of the Se distribution in a mature rice grain slice showed that Se was present throughout the endosperm but was particularly located in the Ovular Vascular Trace (OVT) region (the site of nutrient influx into the grain), the pericarp/aleurone layer, and the embryo [48].

Rice plants growing in a Se-rich environment allowed the demonstration that, within the grain, Se was concentrated in the bran layer, with concentrations almost twice those observed in polished grains. Speciation of the mature grain revealed that Se was present primarily in organic forms, mainly SeMet with lower concentrations of SeMeSeCys and 
SeCys [49], also emphasizing that that Se concentrations in rice decreased in the order rice straw $>$ bran $>$ whole grain $>$ polished rice $>$ husk

Regarding the polishing of rice grain, it is well known that some vitamins and minerals are lost with the removal of husk and bran. The polishing process similar to that of commercial mills, i.e., $8-10 \%$ loss of grain weight, reduced the concentration of $\mathrm{Fe}, \mathrm{Mg}, \mathrm{P}$, $\mathrm{K}$ and $\mathrm{Mn}$ by $60-80 \%$ in all the studied genotypes, while with a smooth polishing ( $3-5 \%$ weight loss) the losses were reduced to a variable degree, according to the ease of polishing the genotypes. The concentration of other elements, e.g., $\mathrm{Zn}, \mathrm{S}, \mathrm{Ca}, \mathrm{Cu}, \mathrm{Mo}$ and $\mathrm{Cd}$, showed comparable reductions $(<30 \%)$ irrespective of polishing technique or ease of polishing [50]. A much greater proportion of Fe is lost by polishing than is the case for $\mathrm{Zn}$. This reflects their distribution pattern within the grain, Fe being mainly confined to the outer grain layers while $\mathrm{Zn}$ is more evenly distributed [50].

These findings agree with our results since the losses of $\mathrm{Cu}$ and $\mathrm{Zn}$ were the lowest ones with reductions, overall, ranging between $25 \%$ and $40 \%$, while $\mathrm{Fe}$, Ca and $\mathrm{K}$ showed decreases generally above $70 \%$, although the DOM was ignored in our case. The loss of Se and $\mathrm{Mg}$ also occurred, seldom exceeding $50 \%$. In Ariete, the Se losses range between approximately $20 \%$ and $30 \%$ and in three cases very small enrichments were detected which are probably related to the distribution of the element within the grain. The losses in Ceres grains were more pronounced, mainly in selenate fertilization using the two highest concentrations with percent values around $60 \%$.

Three different pigmented rice genotypes cultivars were used to access the loss of minerals during the polishing process. The results indicate a huge loss regarding the concentrations of the elements (10) studied in the flour vis-a-vis similar concentrations observed in the flour derived from rough grains [51]. For example, Ca levels decrease between $44 \%$ and $61 \%$ while P levels decrease between $45 \%$ and $80 \%$. Regarding micronutrients, $\mathrm{Fe}$ decreases between 35\% and 70\% whereas Zn decreases between $42 \%$ and $54 \%$ [51].

The effect of milling on the elemental composition of 16 brown rice cultivars was studied [52]. The results indicated that when the DOM was increased twice from $5 \%$ to $10 \%$, elemental percent losses also increased significantly in the majority of the cases $>50 \%$. Only Mo and Zn exhibited lower losses with percentages ranging between $24 \%$ and $34 \%$ and 2.4 and $4.6 \%$, respectively [52]. Thus, it seems that the different patterns of polishing losses of minerals reflected their distribution within the grain, indicating that a careful selection of genotypes with reduced polishing losses must be taken into account [50].

All the data discussed above point out the potential health benefits for the consumption of whole brown rice grain, avoiding in this way the huge loss of nutrients, dietary fiber, and bioactive components and contributing to decrease the prevalence of several chronic diet-related diseases such as type 2 diabetes, hypertension, obesity which are increasing worldwide [53]. Furthermore, studies have suggested that brown rice is associated with a wide spectrum of nutrigenomic implications such as having anti-diabetic, anti-cholesterol, cardio protective and antioxidant properties, due to the presence of various phytochemicals that are mainly located in bran [54]. Thus, it will be important in the near future to continue to develop brown rice-based diets and alert consumers about the importance of changes in eating habits.

\section{Materials and Methods}

\subsection{Experimental Fields}

The trial was conducted under field conditions at the experimental station of the Rice Technological Center (COTARROZ), located in Salvaterra de Magos (39 02'21.8" N; $8^{\circ} 44^{\prime} 22.8^{\prime \prime}$ W). Two rice cultivars, Ariete and Ceres, were tested. The trial duration was from 30 May to 2 November of 2018 and was characterized by maximum and minimum average temperatures of $29^{\circ} \mathrm{C}$ and $18{ }^{\circ} \mathrm{C}$ (with absolute maximum and minimum values of $47^{\circ} \mathrm{C}$ and $9{ }^{\circ} \mathrm{C}$, respectively), with an average rainfall of $0.67 \mathrm{~mm}$ and a daily maximum of $17 \mathrm{~mm}$. Biofortification was carried throughout three foliar sprayings with solutions of sodium selenate $\left(\mathrm{Na}_{2} \mathrm{SeO}_{4}\right)$ and sodium selenite $\left(\mathrm{Na}_{2} \mathrm{SeO}_{3}\right)$ spread during the life cycle of 
the plant. Cultivars were sown in six-row plots with specific equipment for sowing trials and then immediately irrigated.

The experimental design was performed in randomized blocks and a factorial arrangement ( 5 concentrations $\times 2$ forms selenium $\times 2$ cultivars $\times 4$ replicates $=80$ plots $)$. The plot size for each replication was $9.6 \mathrm{~m}^{2}$ ( $8 \mathrm{~m}$ length $\times 1.2 \mathrm{~m}$ width). The agronomic management of trials, namely the application of nitrogen fertilizers, control of weeds, insect pests and diseases and the water management (irrigation) were those recommended and typically used for the rice crop in this region. Furthermore, the accurate characterization, regarding soil characteristics and irrigation water, of the studied area was identical to that described in a previous and recently published work [42], where some climate parameters were also taken into account.

The agronomic Se biofortification comprised three distinct phases. The first Se application occurred at the end of booting, the second one at anthesis and the third at the milky grain stage. The plants were sprayed with $\mathrm{Na}_{2} \mathrm{SeO}_{4}$ and $\mathrm{Na}_{2} \mathrm{SeO}_{3}$ in different concentrations $\left(25,50,75\right.$ and $\left.100 \mathrm{~g} \mathrm{Se} \mathrm{ha}^{-1}\right)$. Controls plants were not sprayed at any time with $\mathrm{Na}_{2} \mathrm{SeO}_{4}$ or $\mathrm{Na}_{2} \mathrm{SeO}_{3}$. Grain harvest occurred on 02 November 2018. In both cultivars, the analysis occurred in the paddy, brown, and white rice grains. In polished rice the husk, bran and germ were removed; thus, it was expected that several minerals, biotin, niacin, proteins, among other constituents, were lost during this process. In brown rice only the husk is removed (sometimes partially the bran), while rough rice or paddy rice is the whole rice grain with its hulls— it comes directly from the field after harvest.

\subsection{Leaf Gas Exchange Measurements}

Leaf gas exchange parameters were determined in the trial field, using 4-6 randomized leaves per treatment, on 12 September, following the methods described elsewhere [55]. Leaf rates of net photosynthesis $\left(P_{n}\right)$, stomatal conductance to water vapor $\left(g_{s}\right)$ and transpiration (E) were obtained under photosynthetic steady-state conditions after ca. $2 \mathrm{~h}$ of illumination (in mid-morning). A portable open-system infrared gas analyzer (Li-Cor 6400, LiCor, Lincoln, NE, USA) was used under environmental conditions, with external $\mathrm{CO}_{2}$ (ca. $400 \mathrm{mg}$. $\mathrm{Kg}^{-1}$ ) and photosynthetic photon flux density (PPFD) of ca. $1000 \mu \mathrm{mol} \mathrm{m}{ }^{-2}$ $\mathrm{s}^{-1}$. Leaf instantaneous water-use efficiency (iWUE) was calculated as the $\mathrm{P}_{\mathrm{n}}$-to-E ratio, representing the units of assimilated $\mathrm{CO}_{2}$ per unit of water lost through transpiration.

\subsection{Atomic Absorption Spectrometry}

After harvest, $1 \mathrm{~g}$ of each sample, previously dried at constant weight, was weighed and placed in a 50-mL Erlenmeyer. An acid digestion procedure was performed with a mixture of $\mathrm{HNO}_{3}-\mathrm{HClO}_{4}(4: 1)$ according the methods described elsewhere [56,57]. This process consists of two sequential steps, the first one using $10 \mathrm{~mL}$ of $\mathrm{HNO}_{3}$, and the second one using $2 \mathrm{~mL}$ of $\mathrm{HNO}_{3}$ plus $3 \mathrm{~mL}$ of $\mathrm{HClO}_{4}$. In both cases, samples were digested at $100-150{ }^{\circ} \mathrm{C}$ until total evaporation. The residue of the final digestion was diluted in a $2 \% \mathrm{HCl}$ solution and filtered (Whatman No. 4) into a 50-mL volumetric flask. The standard solution or the blank was prepared with $2 \% \mathrm{HCl}$ and then analyzed. The concentration of macronutrients $(\mathrm{Ca}, \mathrm{K}$ and $\mathrm{Mg}$ ) in the paddy, brown and white grains was measured by a flame process, using an atomic absorption spectrophotometer model Perkin Elmer AAnalyst 200 fitted with a deuterium background corrector, with the AA WinLab software program.

\subsection{Analysis of Micronutrients and Se Content and Location in the Grain Tissues}

The quantification of $\mathrm{Cu}, \mathrm{Fe}, \mathrm{Zn}$ and Se, plus the localization of Se in the grains, harvested from controls and after foliar spraying with $\mathrm{Na}_{2} \mathrm{SeO}_{4}\left(100 \mathrm{~g} \mathrm{Se} \mathrm{ha}{ }^{-1}\right)$ and $\mathrm{Na}_{2} \mathrm{SeO}_{3}\left(100 \mathrm{~g} \mathrm{Se} \mathrm{ha}^{-1}\right)$ was determined by Energy Dispersive X-Ray Fluorescence ( $\mu$ EDXRF system, M4 Tornado ${ }^{\mathrm{TM}}$, Bruker, Germany), according to Cardoso et al. [58]. The $\mathrm{X}$-ray generator was operated at $50 \mathrm{kV}$ and $100 \mu \mathrm{A}$ without the use of filters, to enhance the ionization of low- $Z$ elements. For a better quantification of Se and other medium to high atomic weight elements, a set of filters between the X-ray tube and the sample, 
composed of three foils of $\mathrm{Al} / \mathrm{Ti} / \mathrm{Cu}$ (with a thickness of $100 / 50 / 25 \mu \mathrm{m}$, respectively), was used. All the measurements with filters were performed with a $600-\mu \mathrm{A}$ current. Detection of fluorescence radiation was performed by an energy-dispersive silicon drift detector, XFlash ${ }^{\mathrm{TM}}$, with $30 \mathrm{~mm}^{2}$ sensitive area and energy resolution of $142 \mathrm{eV}$ for $\mathrm{Mn} \mathrm{K} \alpha$. To better measure the distribution mapping of Se, the rice grain was cut, at the equatorial region, into slices with a stainless-steel surgical blade. Measurements were carried out under 20 mbar vacuum conditions and performed directly on the two sides of grains, in the mapping mode. Quantification analysis was performed on the obtained maps by selecting the area corresponding to the entire grain.

The reference standard material used in this work to assess the quality of the quantification procedure was the ERM BB186 (Pig Kidney) with a certified Se concentration of $10.3 \pm 0.5 \mathrm{mg} \mathrm{Kg}^{-1}$, which is in the same range as the values found in this work. These standards were also used to infer the lower detection and quantification limits for Se which are around 1 and $3 \mathrm{mg} \mathrm{kg}^{-1}$, respectively. Regarding $\mathrm{Cu}$, Fe and $\mathrm{Zn}$ quantification, a set of standard reference materials were used-Orchard Leaves (NBS 1571) and Poplar Leaves (GBW 07604), with recovery rates ranging between $97 \%$ and $99 \%$. The lower detection limit for Fe is $5 \mathrm{mg} \mathrm{kg}^{-1}$, while for $\mathrm{Cu}$ and $\mathrm{Zn}$ it is $2 \mathrm{mg} \mathrm{kg}^{-1}$.

\subsection{Colorimetric Analysis}

The color parameters, using fixed wavelength, adopted the methodology described by Ramalho et al. [59]. Brightness/brightness (L) and chromaticity parameters ( $a^{*}$ and $b^{*}$ coordinates) were obtained with a Minolta CR 300 colorimeter (Minolta Corp., Ramsey, NJ, USA) coupled to a sample vessel (CR-A504). Using the illuminant $\mathrm{D}_{65}$, the system of the Commission Internationale d'Éclaire (CIE) was applied. The parameter L represents the brightness of the sample, translating the variation of the tonality between dark and light, with a range between black (0) and white (100). Parameters $a^{*}$ and $b^{*}$, indicate color variations. The value of $a^{*}$ characterizes coloring in the region from green $(-60)$ to red $(+60)$ and the value $b^{*}$ indicates coloring in the range of between blue $(-60)$ and yellow (+60). The approximation of these coordinates to the null value translates neutral colors like white, gray and black. Measurements were carried out in quadruplicate in the grains of rice at harvest.

\subsection{Statistical Analysis}

Statistical analysis of the data was performed with the IBM SPSS Statistics 20 program, through a one-way analysis of variance and the Tukey's test for mean comparison. A value of $p \leq 0.05$ was considered to be significant.

\section{Conclusions}

The foliar fertilization with Se is an effective method to enrich the Se content of the rice grains despite the losses verified for all the studied elements in polished grains vis-a-vis rough grains. The selenium toxicity threshold was not exceeded, as shown by different evaluations regarding the eco-physiological state of the plant evaluated through leaf gas exchanges. The use of Se fertilizers, at the concentrations used, did not seem to influence the concentration of the different elements in the paddy grain, except Zn. Selenite is the best choice regarding the Se enrichment and in polished grains the concentrations of Se submitted to the different treatments are similar, regardless of the cultivars. The location of Se in dehusked grains (brown rice) showed that, in Ariete cultivar, Se is mostly homogeneously distributed, while in the Ceres cultivar the Se distribution seems to favor accumulation in the periphery, perhaps in the bran. The Se map of the control grains show a fairly homogeneous distribution of Se within the grain with somewhat higher values near the bran, albeit with a very low concentration, especially in the Ariete cultivar. 
Author Contributions: Conceptualization, A.C.M., F.C.L. and F.H.R.; investigation, A.C.M., A.R.F.C., C.C.P., I.C.L.; formal analysis, A.C.M., J.C.R., J.N.S., M.G., R.G.L., P.L., C.G., M.F.P., A.P.R., P.M., C.S., A.R.-B., M.J.S., M.M.S., K.O., D.F., I.P.P.; writing-original draft preparation, A.C.M., F.H.R.; supervision, P.S.C., M.S. and A.S.A. All authors have read and agreed to the published version of the manuscript.

Funding: This research was funded by PDR2020, grant number 101-030671.

Data Availability Statement: Not applicable.

Acknowledgments: The authors give thanks to Paula Marques, Cátia Silva (COTARROZ) and Orivárzea (Orizicultores do Ribatejo, S.A.) for technical assistance. We also give thanks to the Research centers (GeoBioTec) UIDB/04035/2020 and (CEF) UIDB/00239/2020 for support facilities.

Conflicts of Interest: The authors declare no conflict of interest.

\section{References}

1. Garcia-Bañuelos, M.L.; Hermosillo-Cereceres, M.A.; Sanchez, E. The importance of selenium biofortification in food crops. Curr. Nutr. Food Sci. 2011, 7, 181-190. [CrossRef]

2. Broadley, M.; Alcock, J.; Alford, J.; Cartwright, P.; Foot, I.; Fairweather-Tait, S.; Hart, D.; Hurst, R.; Knott, P.; MacGrath, S.; et al. Selenium biofortification of high-yielding winter wheat (Triticum aestivum L.) by liquid or granular Se fertilisation. Plant Soil. 2010, 332, 5-18. [CrossRef]

3. Hart, D.; Fairweather-Tait, S.; Broadley, M.; Dickinson, S.; Foot, I.; Knott, P.; MacGrath, S.; Mowat, H.; Norman, K.; Scott, P.; et al. Selenium concentration and speciation in biofortified flour and bread: Retention of selenium during grain biofortification, processing and production of Se-enriched food. Food Chem. 2011, 126, 1771-1778. [CrossRef] [PubMed]

4. Longchamp, M.; Angeli, N.; Castrec-Rouelle, M. Effects on the accumulation of calcium, magnesium, iron, manganese, copper and zinc of adding the two inorganic forms of selenium to solution cultures of Zea mays. Plant Physiol. Biochem. 2016, 98, 128-137. [CrossRef] [PubMed]

5. Kápolna, E.; Hillestrom, P.R.; Laursen, K.H.; Husted, S.; Larsen, E.H. Effect of foliar application of selenium on its uptake and speciation in carrot. Food Chem. 2009, 115, 1357-1363. [CrossRef]

6. White, P.J. Selenium accumulation by plants. Ann. Bot. 2016, 117, 217-235. [CrossRef]

7. Alshall, T.; El-Ramady, H. Foliar application: From plant nutrition to biofortification. Environ. Biodivers. Soil Secur. 2017, 1, 71-83. [CrossRef]

8. Cakmak, I.; Kutman, U.B. Agronomic biofortification of cereals with zinc: A review. Eur. J. Soil Sci. 2017, 69, 172-180. [CrossRef]

9. Chen, L.; Yang, F.; Xu, J.; Hu, Y.; Hu, Q.; Zhang, Y.; Pan, G. Determination of selenium concentration of rice in China and effect of fertilization of selenite and selenate on selenium content of rice. J. Agric. Food Chem. 2002, 50, 5128-5130. [CrossRef]

10. Boldrin, P.F.; Faquin, V.; Ramos, S.J.; Boldrin, K.V.F.; Ávila, F.W.; Guilherme, L.R.G. Soil and foliar application of selenium in rice biofortification. J. Food Compos. Anal. 2013, 238-244. [CrossRef]

11. Ros, G.; van Rotterdam, A.; Bussink, D.; Bindraban, P. Selenium fertilization strategies for bio-fortification of food: An agroecosystem approach. Plant Soil 2016, 404, 99-112. [CrossRef]

12. Poblaciones, M.J.; Santamaría, O.; García-White, T.; Rodrigo, S.M. Selenium biofortification in bread-making wheat under Mediterranean conditions: Influence on grain yield and quality parameters. Crop Pasture Sci. 2014, 65, 362-369. [CrossRef]

13. Longchamp, M.; Castrec-Rouelle, M.; Biron, P.; Bariac, T. Variations in the accumulation, localization and rate of metabolization of selenium in mature Zea mays plants supplied with selenite or selenate. Food Chem. 2015, 182, 128-135. [CrossRef] [PubMed]

14. Lidon, F.; Oliveira, K.; Galhano, C.; Guerra, M.; Ribeiro, M.; Pelica, J.; Pataco, I.; Ramalho, J.; Leitão, A.; Almeida, A.; et al. Selenium biofortification of rice through foliar application with selenite and selenate. Exp. Agric. 2018, 55, 528-542. [CrossRef]

15. Zhang, Y.; Pan, G.; Chen, J.; Hu, Q. Uptake and transport of selenite and selenate by soybean seedlings of two genotypes. Plant Soil 2003, 253, 437-443. [CrossRef]

16. Hawrylak-Nowak, B. Comparative effects of selenite and selenate on growth and selenium accumulation in lettuce plants under hydroponic conditions. Plant Growth Regul. 2013, 70, 149-157. [CrossRef]

17. Oliveira, K.; Pataco, I.M.; Mourinho, M.P.; Santos, C.; Pelica, J.; Leitão, A.E.; Pais, I.P.; Campos, P.S.; Lidon, F.C.; Reboredo, F.H.; et al. Selenium biofortification in rice-A pragmatic perspective. Emir. J. Food Agric. 2015, 27, 231-241. [CrossRef]

18. Mangueze, A.; Pessoa, M.F.; Silva, M.J.; Ndayiragije, A.; Magaia, H.; Cossa, V.; Reboredo, F.; Carvalho, M.L.; Santos, J.P.; Guerra, M.; et al. Simultaneous zinc and selenium biofortification in rice accumulation, localization and implications on the overall mineral content of the flour. J. Cereal Sci. 2018, 82, 34-41. [CrossRef]

19. Ramalho, J.C.; Roda, F.A.; Pessoa, M.F.G.; Reboredo, F.H.; Pais, I.P.; Ndayiragije, A.; Lidon, F.C.; Ribeiro-Barros, A.I. Selenium agronomic biofortification in rice: Improving crop quality against malnutrition. In The Future of Rice Demand: Quality beyond Productivity; de Oliveira, A.C., Pegoraro, C., Viana, V.E., Eds.; Springer: Cham, Switzerland, 2020; pp. 179-203. [CrossRef]

20. Ramkissoon, C.; Degryse, F.; da Silva, R.C.; Baird, R.; Young, S.D.; Bailey, E.H.; McLaughlin, M.J. Improving the efficacy of selenium fertilizers for wheat biofortification. Sci. Rep. 2019, 9, 19520. [CrossRef] 
21. Zhang, H.; Zhao, Z.; Zhang, X.; Zhang, W.; Huang, L.; Zhang, Z.; Yuan, L.; Liu, X. Effects of foliar application of selenate and selenite at different growth stages on selenium accumulation and speciation in potato (Solanum tuberosum L.). Food Chem. 2019, 286, 550-556. [CrossRef]

22. Hartikainen, H. Biogeochemistry of selenium and its impact of food chain quality and human health. J. Trace Elem. Med. Biol. 2005, 18, 309-318. [CrossRef] [PubMed]

23. Guerrero, B.; Llugany, M.; Palacios, O.; Valiente, M. Dual effects of different selenium species on wheat. Plant Physiol. Biochem. 2014, 83, 300-307. [CrossRef] [PubMed]

24. Marschner, H. Mineral Nutrition of Higher Plants; Academic Press: London, UK, 1995.

25. White, P.; Bowen, H.; Parmaguru, P.; Fritz, M.; Spracklen, W.; Spiby, R.E. Interactions between selenium and sulphur nutrition in Arabidopsis thaliana. J. Exp. Bot. 2004, 55, 1927-1937. [CrossRef] [PubMed]

26. Zhang, D.; Dong, T.; Ye, J.; Hou, Z. Selenium accumulation in wheat (Triticum aestivum L) as affected by coapplication of either selenite or selenate with phosphorus. Soil Sci. Plant Nutr. 2017, 63, 37-44. [CrossRef]

27. Zembala, M.; Filek, M.; Walas, S.; Mrowiec, H.; Kornaś, A.; Miszalski, Z.; Hartikainen, H. Effect of selenium on macro- and microelement distribution and physiological parameters of rape and wheat seedlings exposed to cadmium stress. Plant Soil 2010, 329, 457-468. [CrossRef]

28. Goufo, P.; Ferreira, L.M.M.; Trindade, H.; Rosa, E.A.S. Distribution of antioxidant compounds in the grain of the Mediterranean rice variety 'Ariete'. CyTA J. Food 2015, 13, 140-150. [CrossRef]

29. Almeida, A.S.; Coutinho, J.; Brites, C.; Maçãs, B.; Marques, P.; Silva, C.; Jordão, A. Variedades Portuguesas de Arroz-Presente e Future. Dossier Técnico-Vida Rural. 2020; pp. 42-45. Available online: https://www.drapc.gov.pt/base/documentos/vr_ variedades_portuguesas_\%20arroz.pdf (accessed on 19 January 2021).

30. Zhang, M.; Tang, S.; Huang, X.; Zhang, F.; Pang, Y.; Huang, Q.; Yi, Q. Selenium uptake, dynamic changes in selenium content and its influence on photosynthesis and chlorophyll fluorescence in rice (Oryza sativa L.). Environ. Exp. Bot. 2014, 107, 3945. [CrossRef]

31. Reboredo, F.; Henriques, F. Some observations on the leaf ultrastructure of Halimione portulacoides (L.) Aellen grown in a medium containing copper. J. Plant Physiol. 1991, 137, 717-722. [CrossRef]

32. Jiang, C.; Zu, C.; Lu, D.; Zheng, Q.; Shen, J.; Wang, H.; Li, D. Effect of exogenous selenium supply on photosynthesis, Na ${ }^{+}$ accumulation and antioxidative capacity of maize (Zea mays L.) under salinity stress. Sci. Rep. 2017, 7, 42039. [CrossRef]

33. Hu, Q.; Chen, L.; Xu, J.; Zhang, Y.; Pan, G. Determination of selenium concentration in rice and the effect of foliar application of Se enriched fertilizer or sodium selenite on the selenium content of rice. J. Sci. Food Agric. 2002, 82, 869-872. [CrossRef]

34. Wang, Y.D.; Wang, X.; Wong, Y.S. Generation of selenium-enriched rice with enhanced grain yield, selenium content and bioavailability through fertilisation with selenite. Food Chem. 2013, 141, 2385-2393. [CrossRef] [PubMed]

35. Feng, T.; Chen, S.; Gao, D.; Liu, G.; Bai, H.; Li, A.; Peng, L.; Ren, Z. Selenium improves photosynthesis and protects photosystem II in pear (Pyrus bretschneideri), grape (Vitis vinifera), and peach (Prunus persica). Photosynthetica 2015, 53, 609-612. [CrossRef]

36. González-Morales, S.; Pérez-Labrada, F.; García-Enciso, E.L.; Leija-Martínez, P.; Medrano-Macías, J.; Dávila-Rangel, I.E.; BenavidesMendoza, A. Selenium and sulfur to produce allium functional crops. Molecules 2017, 22, 558. [CrossRef] [PubMed]

37. Turakainen, M.; Hartikainen, H.; Seppanen, M.M. Effects of selenium treatments on potato (Solanum tuberosum L.) growth and concentrations of soluble sugars and starch. J. Agric. Food Chem. 2004, 52, 5378-5382. [CrossRef]

38. Jiang, Y.; Zeng, Z.; Bu, Y.; Ren, C.; Li, J.; Han, J.; Tao, C.; Zhang, K.; Wang, X.; Lu, G. Effects of selenium fertilizer on grain yield, Se uptake and distribution in common buckwheat (Fagopyrum esculentum Moench). Plant Soil Environ. 2015, 61, 371-377. [CrossRef]

39. Thavarajah, P.; Vial, E.; Gebhardt, M.; Lacher, C.; Kumar, S.; Combs, G.F. Will selenium increase lentil (Lens culinaris Medik) yield and seed quality? Front. Plant Sci. 2015, 6, 356. [CrossRef]

40. Da Silva, D.F.; Cipriano, P.E.; de Souza, R.R.; Júnior, M.S.; da Silva, R.F.; Faquin, V.; Silva, M.L.S.; Guilherme, L.R.G. Anatomical and physiological characteristics of Raphanus sativus L. submitted to different selenium sources and forms application. Sci. Hortic. 2020, 260, 108839. [CrossRef]

41. Deng, X.; Liu, K.; Li, M.; Zhang, W.; Zhao, X.; Zhao, Z.; Liu, X. Difference of selenium uptake and distribution in the plant and selenium form in the grains of rice with foliar spray of selenite or selenate at different stages. Field Crops Res. 2017, 211, 165-171 [CrossRef]

42. Marques, A.C.; Lidon, F.C.; Coelho, A.R.F.; Pessoa, C.C.; Luís, I.C.; Scotti-Campos, P.; Simões, M.; Almeida, A.S.; Legoinha, P.; Pessoa, M.F.; et al. Quantification and tissue localization of selenium in rice (Oryza sativa L. Poaceae) grains: A perspective of agronomic biofortification. Plants 2020, 9, 1670. [CrossRef]

43. Lidon, F.C.; Ribeiro, A.; Leitão, A.; Pataco, I.; Ribeiro, M.M.; Reboredo, F.; Almeida, A.; Silva, M.M.; Pais, I.; Pelica, J.; et al. Selenium biofortification of rice grains and implications in the nutritional quality. J. Cereal Sci. 2018, 81, 22-29. [CrossRef]

44. Lamberts, L.; Bie, E.D.; Greet, E.; Vandeputte, W.S.; Veraverbeke, V.; Man, W.; Delcour, J.A. Effect of milling on colour and nutritional properties of rice. Food Chem. 2007, 100, 1496-1503. [CrossRef]

45. Dillahunty, A.L.; Siebenmorgen, T.J.; Mauromoustakos, A. Effect of temperature, exposure duration, and moisture content on color and viscosity of rice. Cereal Chem. 2001, 78, 559-563. [CrossRef]

46. Lu, L.; Tian, S.; Liao, H.; Zhang, J.; Yang, X.; Labavitch, J.; Chen, W. Analysis of metal element distributions in rice (Oryza sativa L.) seeds and relocation during germination based on X-Ray fluorescence imaging of $\mathrm{Zn}, \mathrm{Fe}, \mathrm{K}, \mathrm{Ca}$, and Mn. PLoS ONE 2013, 8, e57360. [CrossRef] [PubMed] 
47. Carey, A.-M.; Lombi, E.; Donner, E.; de Jonge, M.D.; Punshon, T.; Jackson, B.P.; Guerinot, M.L.; Price, A.H.; Meharg, A.A. A review of recent developments in the speciation and location of arsenic and selenium in rice grain. Anal. Bioanal. Chem. 2012, 402, 3275-3286. [CrossRef] [PubMed]

48. Williams, P.N.; Lombi, E.; Sun, G.X.; Scheckel, K.; Zhu, Y.G.; Feng, X.; Zhu, J.; Carey, A.M.; Adomako, E.; Lawgali, Y.; et al. Selenium characterization in the global rice supply chain. Environ. Sci. Technol. 2009, 43, 6024-6030. [CrossRef]

49. Sun, G.X.; Liu, X.; Williams, P.N.; Zhu, Y.G. Distribution and translocation of selenium from soil to grain and its speciation in paddy rice (Oryza sativa L.). Environ. Sci. Technol. 2010, 44, 6706-6711. [CrossRef] [PubMed]

50. Hansen, T.H.; Lombi, E.; Fitzgerald, M.; Laursen, K.H.; Frydenvang, J.; Husted, S.; Boualaphanh, C.; Resurreccion, A.; Howard, D.L.; de Jonge, M.D.; et al. Losses of essential mineral nutrients by polishing of rice differ among genotypes due to contrasting grain hardness and mineral distribution. J. Cereal Sci. 2012, 56, 307-315. [CrossRef]

51. Reddy, C.K.; Kimi, L.; Haripriya, S.; Kang, N. Effects of polishing on proximate composition, physico-chemical characteristics, mineral composition and antioxidant properties of pigmented rice. Rice Sci. 2017, 24, 241-252. [CrossRef]

52. Doesthale, Y.G.; Devara, S.; Rao, S.; Belavady, B. Effect of milling on mineral and trace element composition of raw and parboiled rice. J. Sci. Food Agric. 1979, 30, 40-46. [CrossRef]

53. Saleh, A.S.M.; Wang, P.; Wang, N.; Yang, L.; Xiao, Z. Brown rice versus white rice: Nutritional quality, potential health benefits, development of food products, and preservation technologies. Compr. Rev. Food Sci. Food Saf. 2019, 18, 1070-1096. [CrossRef]

54. Ravichanthiran, K.; Ma, Z.F.; Zhang, H.; Cao, Y.; Wang, C.W.; Muhammad, S.; Aglago, E.K.; Zhang, Y.; Jin, Y.; Pan, B. Phytochemical profile of brown rice and its nutrigenomic implications. Antioxidants 2018, 7, 71. [CrossRef] [PubMed]

55. Rodrigues, W.P.; Martins, M.Q.; Fortunato, A.S.; Rodrigues, A.P.; Semedo, J.N.; Simões-Costa, M.C.; Pais, I.P.; Leitão, A.E.; Colwell, F.; Goulao, L.; et al. Long-term elevated air $\left[\mathrm{CO}_{2}\right]$ strengthens photosynthetic functioning and mitigates the impact of supra-optimal temperatures in tropical Coffea arabica and Coffea canephora species. Glob. Chang. Biol. 2016, 22, 415-431. [CrossRef] [PubMed]

56. Carrondo, M.; Reboredo, F.; Ganho, R.; Santos Oliveira, J.F. Heavy metal analysis of sediments in Tejo estuary, Portugal, using a rapid flameless atomic absorption procedure. Talanta 1984, 31, 561-564. [CrossRef]

57. Reboredo, F.H.S.; Ribeiro, C.A.G. Vertical distribution of Al, $\mathrm{Cu}, \mathrm{Fe}$ and $\mathrm{Zn}$ in soil salt marshes of the Sado estuary, Portugal. Int. J. Environ. Stud. 1984, 23, 249-253. [CrossRef]

58. Cardoso, P.; Mateus, T.; Velu, G.; Singh, R.P.; Santos, J.P.; Carvalho, M.L.; Lourenço, V.M.; Lidon, F.; Reboredo, F.; Guerra, M. Localization and distribution of $\mathrm{Zn}$ and Fe in grains of biofortified bread wheat lines through micro and triaxial-X-ray spectrometry. Spectrochim. Acta Part B At. Spectrosc. 2018, 141, 70-79. [CrossRef]

59. Ramalho, J.C.; Pais, I.P.; Leitão, A.E.; Guerra, M.; Reboredo, F.H.; Máguas, C.M.; Carvalho, M.L.; Scotti-Campos, P.; Ribeiro-Barros, A.I.; Lidon, F.J.C.; et al. Can elevated air $\left[\mathrm{CO}_{2}\right]$ conditions mitigate the predicted warming impact on the quality of coffee bean? Front. Plant Sci. 2018, 9, 287. [CrossRef] [PubMed] 